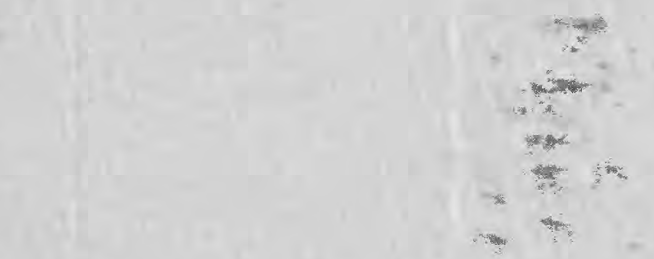

\title{
Compositional Variations and
}

Abundances of Selected Elements

in Granitoid Rocks and

Constituent Minerals, Central

Sierra Nevada Batholith, California

GEOLOGICAL SURVEY PROFESIONAL PAPER 1248

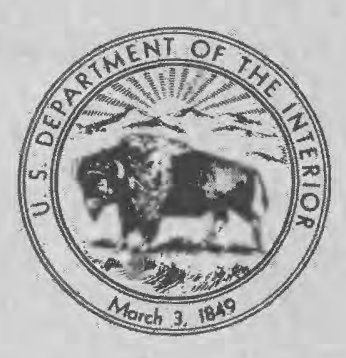




\section{Compositional Variations and}

Abundances of Selected Elements

in Granitoid Rocks and

Constituent Minerals, Central

\section{Sierra Nevada Batholith, California}

By F. C. W. DODGE, H. T. MILLARD, JR., and H. N. ELSHEIMER

GEOLOGICAL SURVEY PROFESIONAL PAPER 1248

A geochemical study of the lateral compositional

variations in granitoid rocks across the

central Sierra Nevada batholith

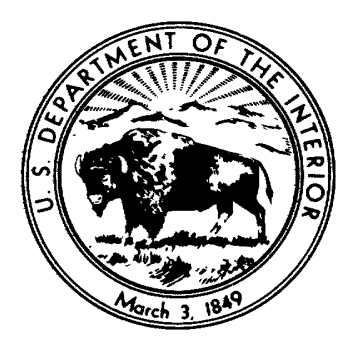




\title{
UNITED STATES DEPARTMENT OF THE INTERIOR JAMES G. WATT, Secretary
}

\author{
GEOLOGICAL SURVEY \\ Dallas L. Peck, Director
}

Library of Congress Catalog Card No. 82-600541

For sale by the Superintendent of Documents, U.S. Government Printing Office Washington, D.C. 20402 


\section{CONTENTS}

Abstract
Introduction
Background summary
Analytical procedures
Elemental abundances and compositional variations
Rare-earth elements
Alkali metals and alkaline earths
Elements covariant with iron
$\quad$ Variations of other elements
$\quad$ Variations across the batholith
$\quad$ Variations relative to SiO
Conclusions
References cited ...............

\section{ILLUSTRATIONS}

Figures 1-17. Graphs showing:

1. Twelve representative chondrite-normalized rare-earth-element patterns of Sierra Nevada granitoids ...............

2. Rare-earth-element mineral-rock ratios or ranges of ratios for some constituent minerals of Sierra Nevada granitoids

3. Potassium plotted against caesium and rubidium for Sierra Nevada granitoids

4. Atomic proportions of large alkali metals in potassium-feldspars and biotites of Sierra Nevada granitoids

5. Potassium plotted against barium for Sierra Nevada granitoids and constituent biotites and potassiumfeldspars

6. Cobalt plotted against iron for Sierra Nevada granitoids

7. Scandium plotted against iron for Sierra Nevada granitoids and constituent ferromagnesian minerals

8. Vanadium plotted against iron for Sierra Nevada granitoids

9. Uranium plotted against thorium for Sierra Nevada granitoids

10. Hafnium plotted against zirconium for Sierra Nevada granitoids

11. Uranium and thorium in biotites, hornblendes, and feldspars relative to host granitoids

12. Total rare-earth elements plotted onto a line approximately normal to the axis of the Sierra Nevada batholith

13. Correlation coefficients $(r)$ of total rare-earth elements and individual rare-earth elements relative to easterly distance across the batholith

14. Tantalum plotted onto a line approximately normal to the axis of the Sierra Nevada batholith

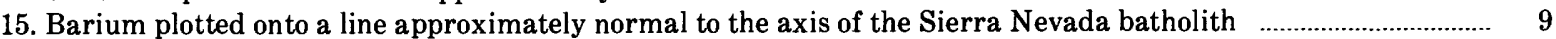

16. Selected elements and elemental ratios plotted against silica for Sierra Nevada granitoids ..................................... 10

17. Solid/liquid distribution coefficients of rare-earth elements for minerals of mafic and intermediate rocks .......... 12

\section{TABLES}




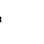




\title{
COMPOSITIONAL VARIATIONS AND ABUNDANCES OF SELECTED ELEMENTS IN GRANITOID ROCKS AND CONSTITUENT MINERALS, CENTRAL SIERRA NEVADA BATHOLITH, CALIFORNIA
}

\author{
By F. C. W. Dodge, H. T. Millard, Jr., and H. N. Elsheimer
}

\begin{abstract}
Contents of several elements have been determined in 27 representative granitoid samples from the central Sierra Nevada batholith and in 36 separates of their major constituent minerals. The chemical data confirm some previously established lateral compositional trends and also demonstrate eastward increase in light rareearth elements and tantalum across the batholith. These variations are attributable to the heterogeneity of the source regions from which magmas were derived.

Continuous fractionation of ferromagnesian minerals throughout the differentiation history of Sierra Nevada magmas is suggested by systematic decrease of iron and a group of related trace elements with increasing $\mathrm{SiO}_{2}$. Chemical and mineralogical evidence indicate that hornblende dominated fractionation when the magma contained 55-72 percent $\mathrm{SiO}_{2}$, and at higher $\mathrm{SiO}_{2}$ levels iron depletion reflects removal of small amounts of magnetite. Biotite was apparently not an important fractionated phase. Below 72 percent $\mathrm{SiO}_{2}$, several elemental variations are largely controlled by hornblende fractionation, whereas above 72 percent both strontium and $\mathrm{Eu} / \mathrm{Eu}^{*}$ drop abruptly indicating a shift to plagioclase as a controlling fractionate. The low barium content of a high $\mathrm{SiO}_{2}$ leucogranite implies $\mathrm{K}$-feldspar depletion, and the rock may be a true eutectic granite.
\end{abstract}

\section{INTRODUCTION}

In recent years there has been increasing realization that knowledge of the distribution of chemical constituents provides important evidence for origin and magmatic history of granitic batholiths. In the Sierra Nevada batholith, which has been intensively studied in a wide belt across its central part between lat $36^{\circ} 45^{\prime}$ and $38^{\circ} 00^{\prime} \mathrm{N}$., the gross distribution of its chemical constituents is difficult to discover because the batholith is made up of many differing plutonic bodies. For this study, part of a continuing program of geochemical study of this batholith, the chemical constituents in 27 samples of granitoid rocks and in 36 separates of their major constituent minerals have been determined. Analyses by neutron activation and X-ray fluorescence have revealed the distribution of several elements, including rare-earth elements (REE) and alkali metals.

Rock samples used in this investigation are from carefully identified localities and were collected as representative of mapped rock units (table 1). The same samples have been used in many other detailed studies of the batholith: for example, Hurley and others, 1965; Kistler and others, 1965; Dodge and others, 1968, 1969; Piwinskii, 1968; Naeser and Dodge, 1969; Bateman and Dodge, 1970; and the samples have been previously analyzed for major element oxides and have been studied petrographically.

\section{BACKGROUND SUMMARY}

The Sierra Nevada batholith is a composite of many plutonic bodies ranging in outcrop area from less than a square kilometer to several hundred square kilometers. Individual bodies are either in sharp contact with one another or are separated by remnants of metamorphosed sedimentary and volcanic rocks.

Several of the bodies in the central Sierra Nevada have been grouped into intrusive sequences. Each sequence consists of rocks emplaced during a single intrusive epoch; field, petrographic, and chemical data suggest that the rocks in each sequence are cogenetic. Within individual sequences there is a chronological progression from mafic to felsic; the oldest rocks have silica contents as low as 55 weight percent and contain abundant hornblende, biotite, and intermediate plagioclase. Successively younger rocks in each sequence have increasingly greater silica contents, lesser hornblende and biotite, and more sodic plagioclase. The youngest rocks in some sequences have as much as 80 weight percent silica, contain abundant quartz, K-feldspar, and sodic plagioclase, and are void of hornblende.

Lateral gross compositional changes across the entire batholith are superimposed on the recurrent compositional variations within individual sequences. A study by Bateman and Dodge (1970) of variation of major chemical constituents showed clearly that $\mathrm{K}_{2} \mathrm{O}$ increases systematically eastward, suggested that $\mathrm{Fe}_{2} \mathrm{O}_{3}$ and $\mathrm{TiO}_{2}$ may also increase eastward, but that $\mathrm{FeO}, \mathrm{MgO}$, and $\mathrm{CaO}$ may decrease, and indicated no significant change in amount of $\mathrm{SiO}_{2}, \mathrm{Al}_{2} \mathrm{O}_{3}, \mathrm{Na}_{2} \mathrm{O}$, 
$\mathrm{H}_{2} \mathrm{O}, \mathrm{P}_{2} \mathrm{O}_{5}$, and $\mathrm{MnO}$ across the batholith. The oxidation ratio $\left[\mathrm{mol}\left(2 \mathrm{Fe}_{2} \mathrm{O}_{3} \times 100\right) /\left(2 \mathrm{Fe}_{2} \mathrm{O}_{3}+\mathrm{FeO}\right)\right]$ increases eastward (Dodge, 1972a). In addition, the minor elements rubidium, uranium, thorium, and beryllium have been shown to increase eastward (Dodge, 1972b) as does the initial ${ }^{87} \mathrm{Sr} /{ }^{86} \mathrm{Sr}$ ratio (Kistler and Peterman, 1973). Batholithic rocks generally range in age from Triassic to middle Cretaceous (Evernden and Kistler, 1970); however, the regional compositional patterns are independent of age patterns (Kistler, 1974). The age succession, from oldest to youngest, of the intrusive sequences mentioned in this report is: Scheelite, Palisade, Fine Gold, Shaver (Taft Granite is tentatively included with the Shaver), and John Muir; the generalized geographic position, from west to east is: Fine Gold, Shaver, John Muir, Palisade, and Scheelite.

\section{ANALYTICAL PROCEDURES}

Rocks analyzed in this study were selected from a suite of intensively studied samples. Separates of several constituent minerals were prepared for analysis from carefully sized rock powders of some of the same rock samples by electromagnetic and density concentration. With the exception of plagioclase and quartz, which generally could not be separated from one another, final sample purity of individual separates generally exceeded 98 percent.

Rocks and major mineral phases were analyzed by instrumental neutron activation analysis (Gordon and others, 1968; Hertogen and Gijbels, 1971) for REE, alkali metals, and an assortment of other elements. Splits of 1.5 grams of rock powders, mineral separates, and standards (U.S. Geol. Survey standard rock G-2 and synthetic standards prepared by mixing elements with high-purity quartz powder) were irradiated for 30 minutes in the USGS Denver TRIGA reactor in a neutron flux of $3 \times 10^{10} \mathrm{n} / \mathrm{cm}^{2} / \mathrm{s}$, and then counted over a 4-hour decay interval using coaxial $\mathrm{Ge}(\mathrm{Li})$ detectors (resolution $2.0 \mathrm{keV}$ FWHM at $1333 \mathrm{keV}$, efficiency $\sim 10$ percent). The samples and standards were then irradiated for a second time for 8 hours in a neutron flux of $3 \times 10^{12} \mathrm{n} / \mathrm{cm}^{2} / \mathrm{s}$ and counted with both coaxial $\mathrm{Ge}(\mathrm{Li})$ detectors and planar $\mathrm{Ge}(\mathrm{Li})$ detectors (resolution $\sim 500$ eV FWHM at $122 \mathrm{keV}$ ) after decay times of 7, 14, and 60 days. Spectra of induced gamma-ray activities were stored on magnetic tape, and areas under photopeaks were calculated and compared to the standards by computer. A few of the elements determined by neutron activation in this study have been determined on some of the materials in other studies (for example, Dodge and others, 1968, 1969, 1970; Greenland and others, 1968, 1971; Wollenberg and Smith, 1968; Til- ling and others, 1969); in general, agreement with previous analyses is satisfactory.

Rock analyses for $\mathrm{Sr}, \mathrm{V}$, and $\mathrm{Ni}$ were performed on pressed cellulose powder pellets with a sample/cellulose ratio of $85 / 15$. Conventional $\mathrm{X}$-ray fluorescence techniques were employed utilizing an automated, computerized X-ray spectrometer system. Results were determined using previously established calibration curves for standard silicate rocks; the curves were generated using multiple linear regression equations taking into account various matrix effects.

\section{ELEMENTAL ABUNDANCES AND COMPOSITIONAL VARIATIONS}

Rock analyses have been grouped in table 2 according to rock type using the classification and nomenclature recommended by the IUGS Subcommission on the Systematics of Igneous Rocks and are arranged within groups in order of increasing silica contents. Mineral analyses of tables 3 through 7 are listed simply in order of increasing silica contents of host rocks.

\section{RARE-EARTH ELEMENTS}

$\mathrm{REE}$ data on the granitoid rocks have been normalized to chondrite values summarized by Hermann (1970). Twelve chondrite normalized patterns are shown in figure 1 . The patterns show an overall REE enrichment and heavy REE depletion relative to light REE. They are generally similar to those determined by Frey, Chappell, and Roy (1978) for granitoid rocks of the Tuolumne Intrusive Series of the central Sierra Nevada, except for lower light REE in a quartz gabbro (CL-1) and a trondjhemite (ST-1) and the presence of large negative Eu anomalies $\left(\mathrm{Eu} / \mathrm{Eu}^{*}\right.$, the ratio of the actual chondrite-normalized $\mathrm{Eu}$ value to the chondrite-normalized Eu value if there were no anomaly, of less than 0.5) in four leucogranite samples (FD12, HL-29, R-99, MG-2). Undetermined REE values have been estimated by extrapolation using chondritenormalized diagrams. Total REE contents range from 74 to $250 \mathrm{ppm}$ if the determined values are added to the estimated values. La/Yb ratios range from 2.9 to 48 , but the ratios for three-quarters of the samples range between 15 and 40 .

Contents of REE in separates of major mineral phases from the Sierra Nevada granitoid rocks are generally somewhat lower than contents reported on the same minerals from granitic suites in other regions (for example, Towell and others, 1965; Buma and others, 1971; Masuda and others, 1972), whereas REE contents of Sierra Nevada accessory sphenes and apatites (Dodge and -Mays, 1972) are similar to those 

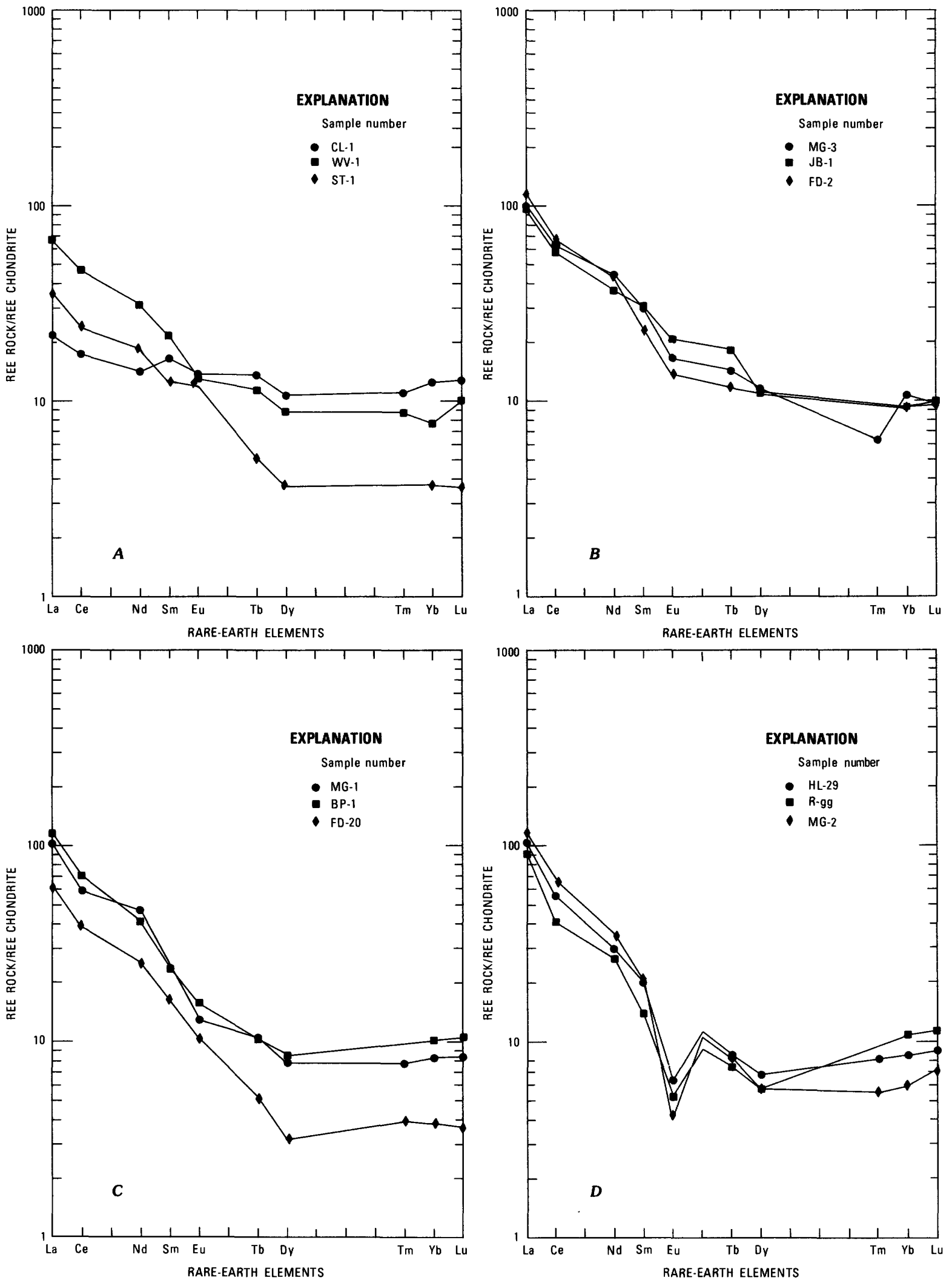

Figure 1.-Twelve representative chondrite-normalized rare-earth-element patterns of Sierra Nevada granitoids. A, Plagioclase-rich granitoids, B, quartz monzodiorites, C, granodiorites, and D, leucogranites. 
reported from several granitic suites in other regions (for example, Towell and others, 1965; Lee and others, 1969, 1973; Nagasawa, 1970; Staatz and others, 1977). As noted by Towell, Winchester, and Spirn (1965), small amounts of accessory mineral impurities would concentrate relatively large amounts of REE in major mineral phases, and the bulk of REE in magnetites (table 7) are probably contained in accessory mineral impurities. The Sierra Nevada separates are as pure as is practicable without resorting to acid washing. Nagasawa (1970) has shown that, at least in zircon, acid washing preferentially leaches the lighter REE.

The range of mineral/rock ratios for hornblendes, $\mathrm{K}$-feldspars, and sphenes, based on 12 sphene analyses used by Dodge and Mays (1972) from the same rocks as those analyzed in this study, and the ratios for a plagioclase are shown in figure 2 . Ranges are not shown for biotites, as only a relative few of the REE have been determined, or for magnetites. The mineral/rock ratios fall within rather limited ranges and are similar to mineral/groundmass partition coefficients for $\mathrm{REE}$ in

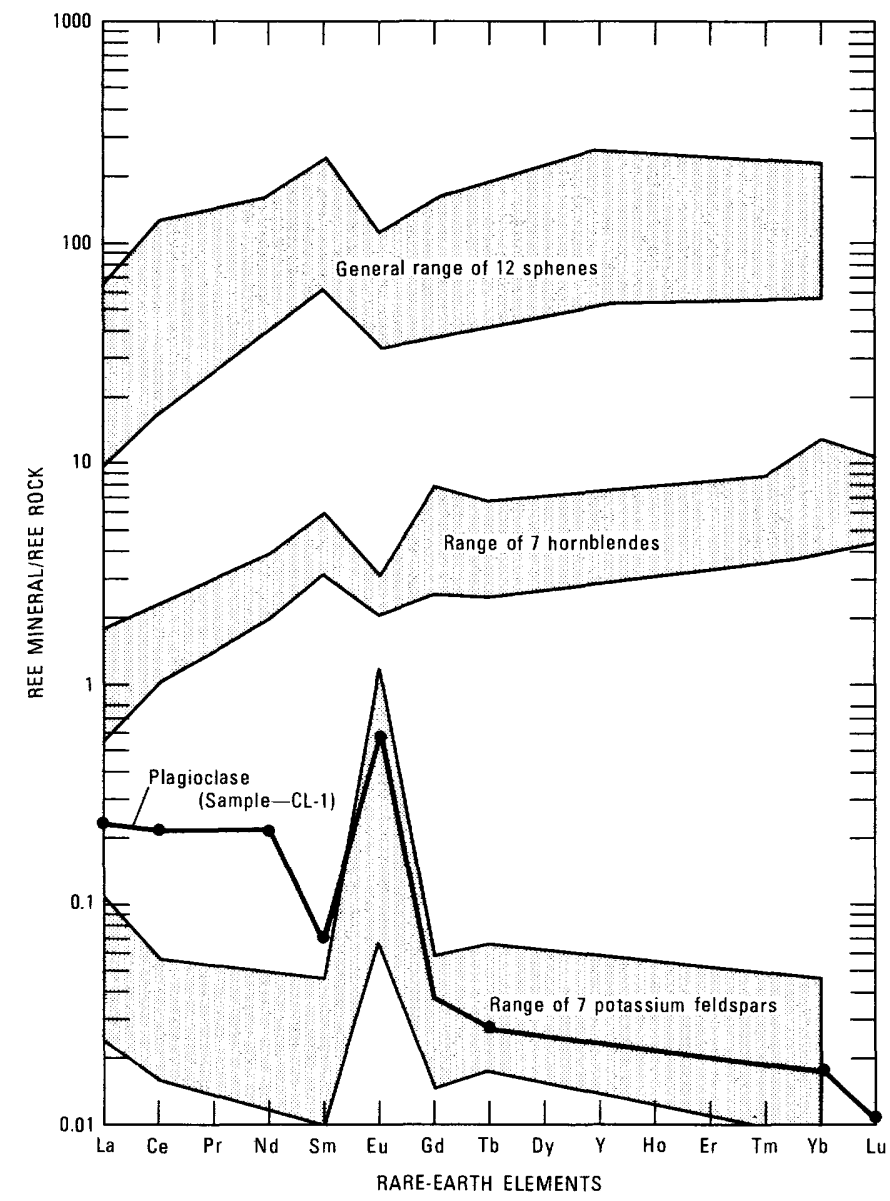

Figure 2.-Rare-earth-element mineral-rock ratios or ranges of ratios for some constituent minerals of Sierra Nevada granitoids. dacitic volcanic rocks (for example, Higuchi and Nagasawa, 1969; Schnetzler and Philpotts, 1970; Nagasawa and Schnetzler, 1971; Arth and Barker, 1976).

\section{ALKALI METALS AND ALKALINE EARTHS}

Sodium in the granitoid rocks shows little relation to the other alkalis. Bateman and Dodge (1970) showed $\mathrm{Na}_{2} \mathrm{O}$ ranged from less than 2 to over 5 weight percent in 193 samples of Sierra Nevada granitoids, but 80 percent of the samples contained between 3 and 4 percent $\mathrm{Na}_{2} \mathrm{O}$. The 27 rock samples of the study have $\mathrm{Na}_{2} \mathrm{O}$ within or very near the 3 to 4 percent range.

The relation between $\mathrm{K}$ and the two less abundant large alkali metals, $\mathrm{Rb}$ and $\mathrm{Cs}$, is shown in figure 3 . Potassium ranges a full magnitude from 0.484 to 4.01 weight percent (0.583-4.83 percent $\mathrm{K}_{2} \mathrm{O}$ ), $\mathrm{Rb}$ from 13.8 to $182 \mathrm{ppm}$, though not determined in the least potassic sample (CL-1), and Cs from 1.10 to $8.56 \mathrm{ppm}$. Rubidium varies positively with $\mathrm{K}$ throughout the entire suite, as shown previously by Dodge, Fabbi, and Ross (1970) and Kistler and Peterman (1973) for Sierra Nevada granitoid rocks. Although there is considerable scatter in the K-Cs plot, it is apparent that the relationship of Cs to $K$ is quite different from that of $R b$ to $\mathrm{K}$. In low $\mathrm{K}$ samples, Cs is low, but tends to increase with increasing $\mathrm{K}$ to a maximum at 2 weight percent $\mathrm{K}$, then abruptly decreases at higher $\mathrm{K}$ contents.

Relative contents of the three large alkali metals in $\mathrm{K}$-feldspar and biotites, which contain the bulk of these elements in the granitoid rocks, are shown in figure 4. Rubidium is concentrated in biotite (498$1,740 \mathrm{ppm})$ relative to $\mathrm{K}$-feldspar (212-468 ppm), and Cs is even more relatively concentrated in the biotite (10.1 to $157 \mathrm{ppm}$ ) compared to $\mathrm{K}$-feldspar (1.15 to 5.70 ppm); similar relations have been reported by Carron and Lagache (1972) and Bernotat, Carron, and Lagache (1976) among others. The dropoff of Cs in rocks with high $\mathrm{K}$ contents reflects the decreasing amounts of biotite contained in these rocks, an effect probably present but not so pronounced for Rb.

Barium, generally thought to be characterized by its ability to substitute for $\mathrm{K}$, shows a rather poor correlation with K (fig. 5). Bateman and Chappell (1979) have also noted that $\mathrm{Ba}$, which they expected to follow $\mathrm{K}$, is unexpectedly erratic in its behavior in the Tuolumne Intrusive Series of the central Sierra Nevada. Of the two potassic minerals, K-feldspar and biotite, Ba tends to be much more highly concentrated in the former (fig. 5). K-feldspar has an average $\mathrm{K} / \mathrm{Ba}$ ratio of only 28 , whereas biotite has an average ratio of 94 , and if a single biotite which does not coexist with $\mathrm{K}$-feldspar is excluded, the ratio is even greater at 100 . The presence of significant amounts of $\mathrm{Ba}$ in both hornblende and 


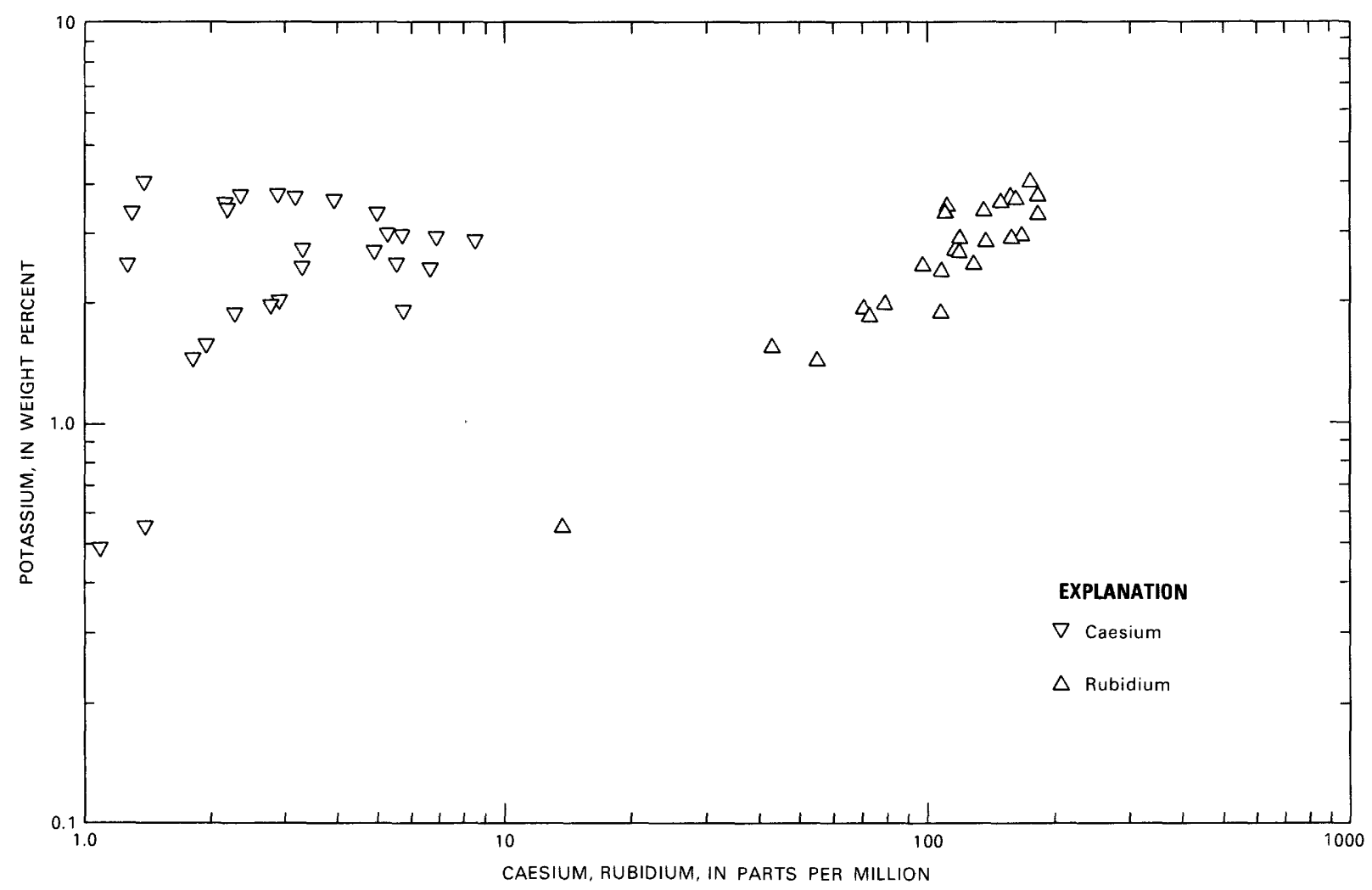

Figure 3.-Potassium plotted against caesium and rubidium for Sierra Nevada granitoids.

plagioclase may help account for the rather poor correlation of $\mathrm{Ba}$ with $\mathrm{K}$.

Evernden and Kistler (1970) and Kistler and Peterman (1973) recorded a range of 86 to $764 \mathrm{ppm} \mathrm{Sr}$ and of 0.14 to $2.14 \mathrm{Rb} / \mathrm{Sr}$ for Sierra Nevada granitoid rocks. With the exception of a leucogranite sample with 42 $\mathrm{ppm} \mathrm{Sr}$ and $4.14 \mathrm{Rb} / \mathrm{Sr}$, all samples of this study are within these ranges. We do not present data for $\mathrm{Sr}$ in mineral analyses herein; however, relatively low $\mathrm{Sr}$ values of 16-65 ppm have been reported for hornblendes (Dodge and others, 1968) and of less than 6-28 ppm for biotites (Hurley and others, 1965; Dodge and others, 1969) from granitoids of the central Sierra Nevada. These values were determined on many of the same mineral separates analyzed in the present study. In addition, the following $\mathrm{Sr}$ values have been determined spectrographically on four of the K-feldspars of table 6(R. E. Mays, written commun.): HL-29, $40 \mathrm{ppm}$; BP-1, 120 ppm; MG-1, 150 ppm; MG-3, 240 ppm. Thus, the major rock-forming minerals, hornblende, biotite, and $\mathrm{K}$-feldspar, all have considerably lower $\mathrm{Sr}$ contents than their respective host rocks, and the bulk of the $\mathrm{Sr}$ in the granitoids is believed to be contained in plagioclase feldspar.

\section{ELEMENTS COVARIANT WITH IRON}

Several elements, including Sc, $\mathrm{V}, \mathrm{Cr}, \mathrm{Mn}, \mathrm{Co}$, and
$\mathrm{Ni}$, show a high positive correlation with $\mathrm{Fe}(r=0.6)$ and are largely concentrated in the ferromagnesian minerals. The plot of Co against Fe (fig. 6) and Sc against $\mathrm{Fe}$ (fig. 7) in the granitoids illustrates the close relations between these elements exceptionally well. Vanadium shows two distinctly different, though strongly positive, trends relative to $\mathrm{Fe}$ (fig. 8). The reason for the divergent $\mathrm{V}$ trends is not clear.

Although these elements are concentrated in the ferromagnesian minerals, consistent strong partitioning of the elements between coexisting individual ferromagnesian minerals is shown only by $\mathrm{Cr}$, which is generally concentrated in magnetite, and importantly by Sc, which is enriched in hornblende, concentrated to a lesser extent in biotite, and impoverished in magnetite (fig. 7). This partitioning is further shown by the greater Sc contents of hornblende-bearing rocks relative to hornblende-free rocks. Interestingly, biotites that do not coexist with hornblendes have greater Sc contents than those that do. Vanadium and Ni were determined only on whole rocks in this study; however, previous work on constituent biotites and hornblendes (Dodge and others, 1968, 1969) show little partitioning of these elements.

\section{VARIATIONS OF OTHER ELEMENTS}

Of the potpourri of remaining determined elements, 


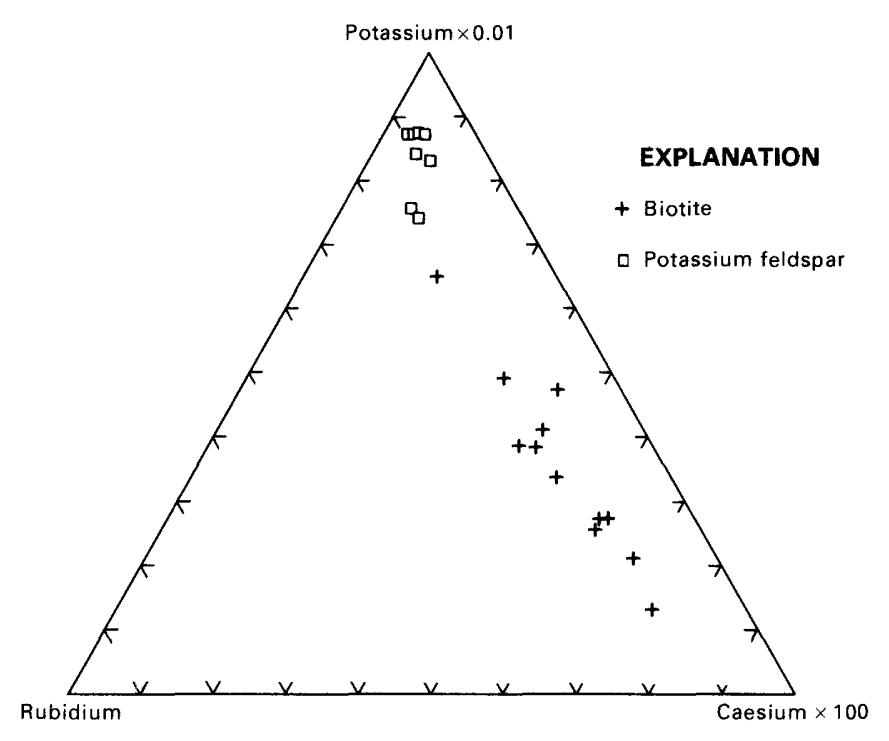

Figure 4.-Atomic proportions of large alkali metals in potassium feldspars and biotites of Sierra Nevada granitoids.
U and Th (fig. 9) and Zr and Hf (fig. 10) are geochemically coherent pairs.

Uranium and Th contents and the U/Th ratios of the analyzed rocks are similar to those determined by Wollenberg and Smith (1968) on numerous samples from the central Sierra Nevada batholith. Feldspars tend to contain less Th relative to their host rocks than do biotites or hornblendes, whereas $U$ contents normalized to host granitoid rocks for all these minerals show no consistent differences (fig. 11). The bulk of the U and $\mathrm{Th}$ in these rocks is undoubtedly concentrated in accessory phases, particularly zircon, sphene, allanite, and monazite (Wollenberg, 1973).

$\mathrm{The} \mathrm{Zr} / \mathrm{Hf}$ ratio of the granitoids falls in a limited range from 35 to 60 . The bulk of the $\mathrm{Zr}$ is believed to be present in accessory zircon, and $\mathrm{Zr}$ values are not given for mineral separates. It is of interest that Hf contents of hornblende generally exceed those of biotite by nearly an order of magnitude; a single exception is a biotite (ST-1) which contains appreciable Hf and does not coexist with hornblende.

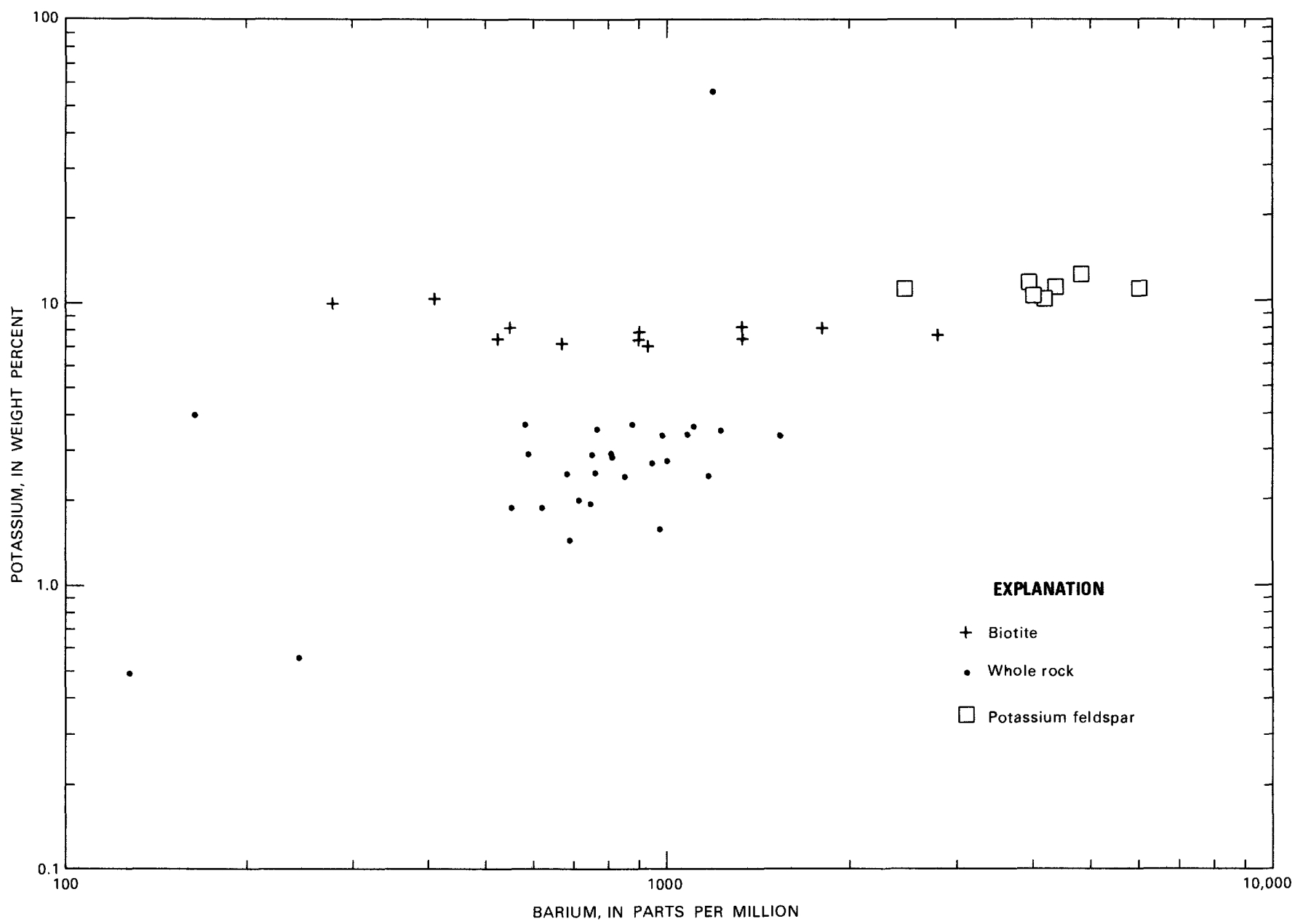

Figure 5.-Potassium plotted against barium for Sierra Nevada granitoids and constituent biotites and potassium feldspars. 


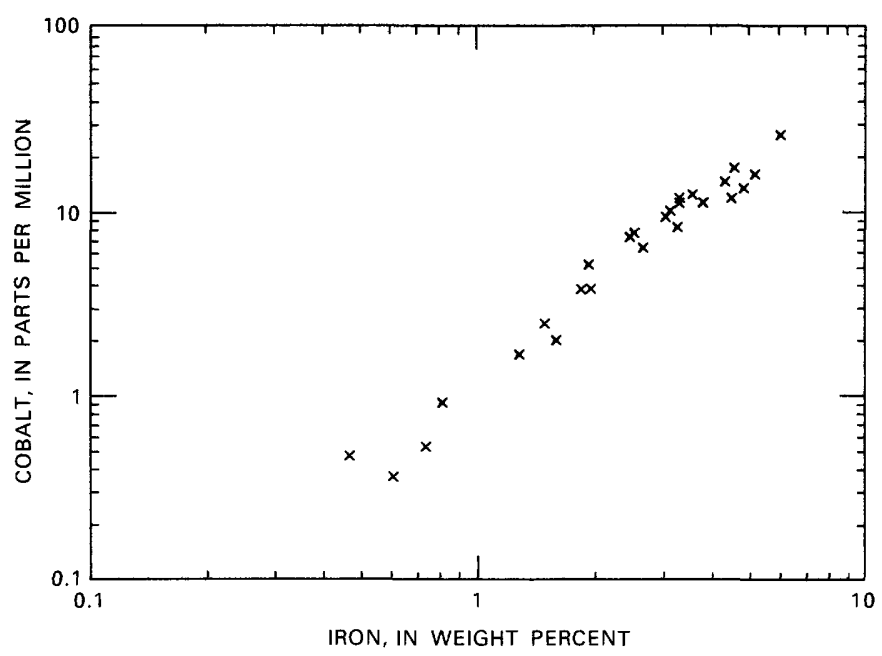

Figure 6.-Cobalt plotted against iron for Sierra Nevada granitoids.

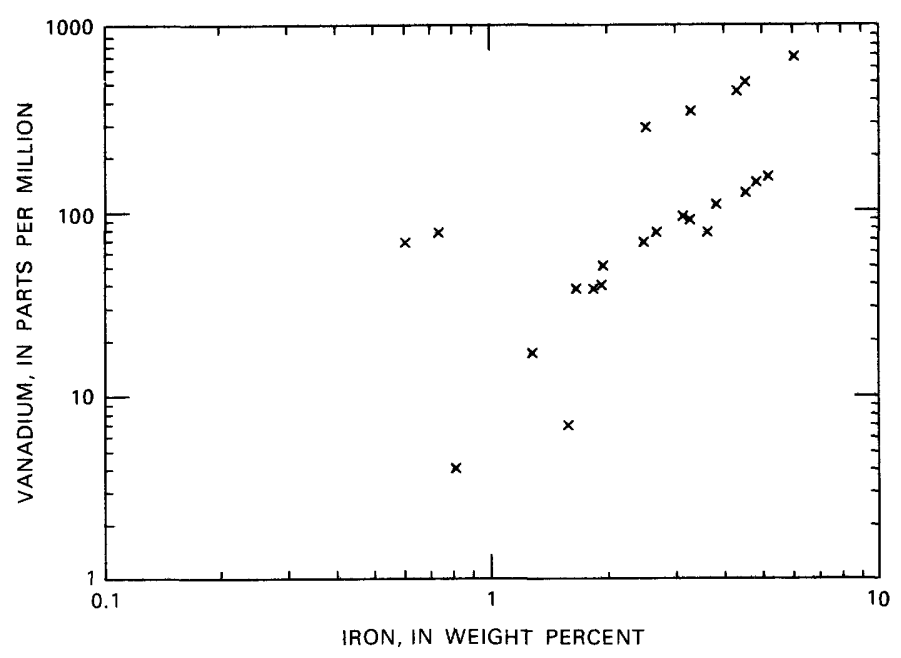

Figure 8.-Vanadium plotted against iron for Sierra Nevada granitoids.

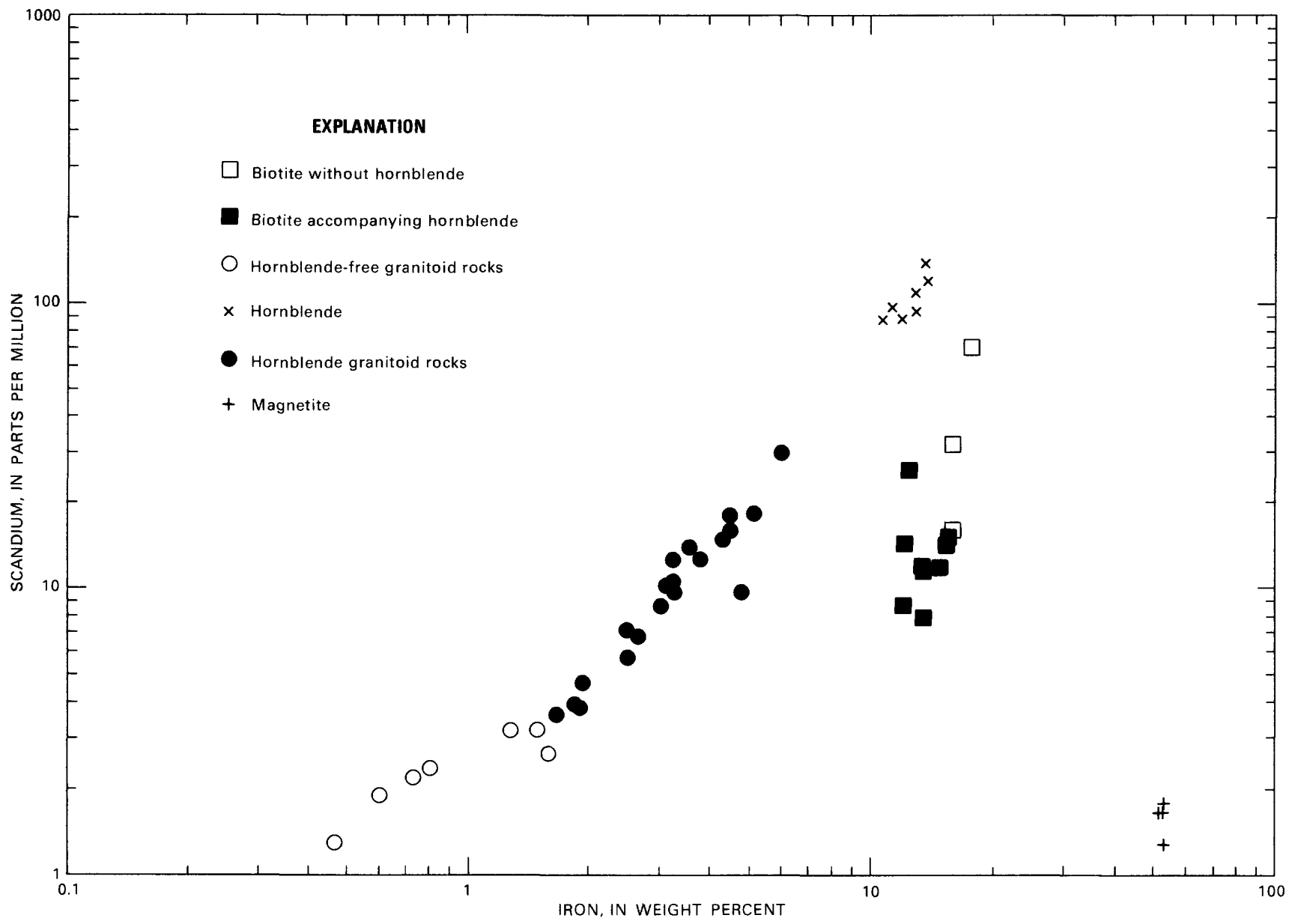

Figure 7.-Scandium plotted against iron for Sierra Nevada granitoids and constituent ferromagnesian minerals. 


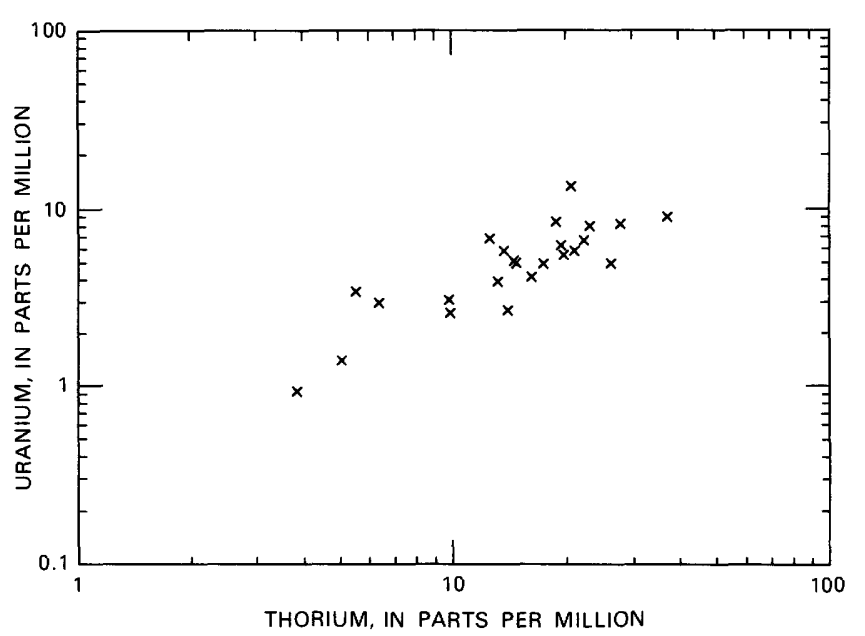

Figure 9.-Uranium plotted against thorium for Sierra Nevada granitoids.

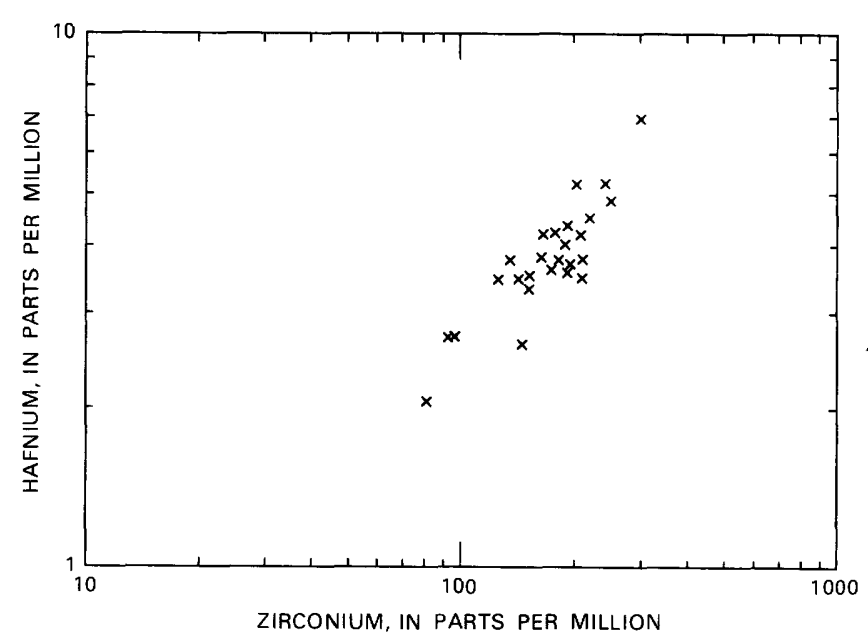

Figure 10.-Hafnium plotted against zirconium for Sierra Nevada granitoids.

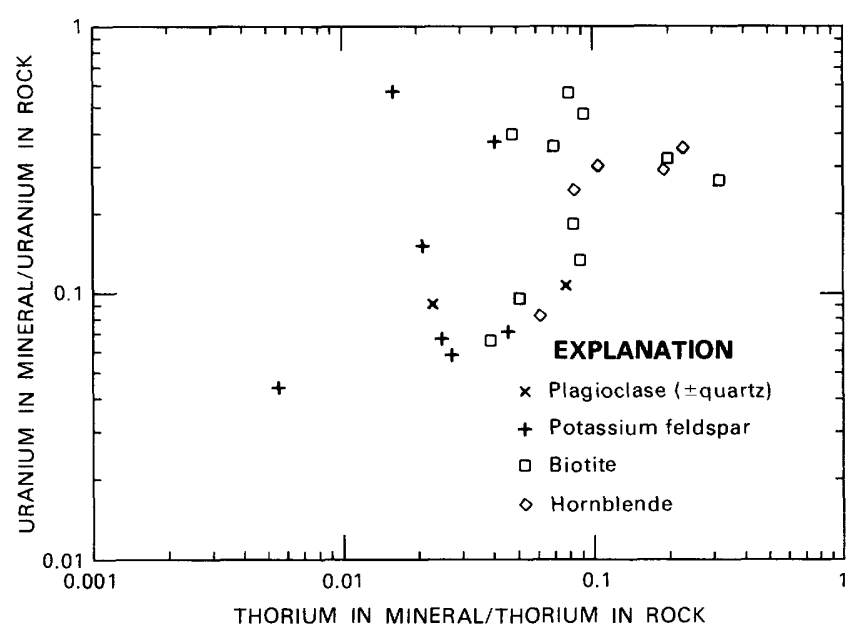

Figure 11.-Uranium and thorium in biotites, hornblendes, and feldspars relative to host granitoids.
Distribution of Ta in Sierra Nevada granitoids is similar to its distribution in rocks of the southern California batholith (Gottfried and Dinnin, 1965); however, overall the element is more abundant in the Sierran rocks, ranging from about $0.2 \mathrm{ppm}$ in two plagioclase-rich granitoids to more than $2 \mathrm{ppm}$ in a leucogranite. Hornblende generally contains greater amounts of Ta than coexisting biotite although biotites from hornblende-free rocks are especially enriched in the element.

Antimony, which ranges from less than 0.1 to more than $1.0 \mathrm{ppm}$ in the granitoids, shows little relation to other determined elements. Greatest Sb contents are in hornblendes, and, unlike Ta, biotites from hornblende-free rocks are not enriched in $\mathrm{Sb}$.

\section{VARIATIONS ACROSS THE BATHOLITH}

Previous workers (Wollenberg and Smith, 1968; Bateman and Dodge, 1970; Dodge and others, 1970; Dodge, 1972a, b; Kistler and Peterman, 1973) have demonstrated eastward increase in $\mathrm{K}, \mathrm{Rb}, \mathrm{U}, \mathrm{Th}, \mathrm{Be}$, and the initial ${ }^{87} \mathrm{Sr} /{ }^{86} \mathrm{Sr}$ ratio and the oxidation ratio, that is, the molecular ratio $\left(2 \mathrm{Fe}_{2} \mathrm{O}_{3} \times 100\right) /\left(2 \mathrm{Fe}_{2} \mathrm{O}_{3}+\right.$ $\mathrm{FeO}$ ), across the central Sierra Nevada batholith. Although our data are limited to a few samples, they confirm some of these trends and indicate others may be coexistent.

The most important other geographic trend is that of total REE. In figure 12, the total $\mathrm{REE}$, including values estimated from chondrite-normalized diagrams, are plotted onto a line which crosses the batholith approximately normal to its axis. Although there is some scatter, total REE clearly increases gradually from an average of about $80 \mathrm{ppm}$ in the western Sierra

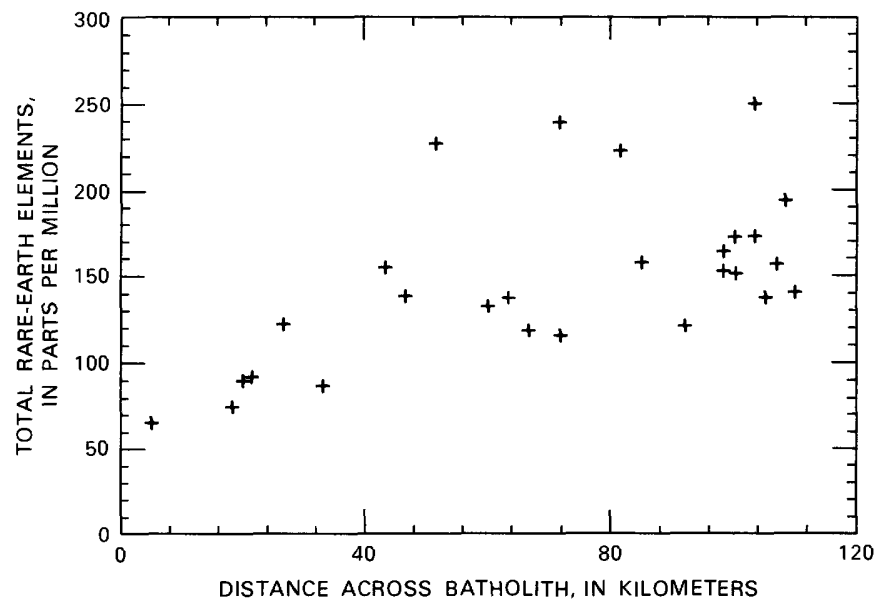

Figure 12.-Total rare-earth elements plotted onto a line approximately normal to the axis of the Sierra Nevada batholith. 
Nevada foothills to over $160 \mathrm{ppm}$ in the eastern part of the batholith. Of the $14 \mathrm{REE}$, the lightest 2, La and Ce, constitute from one- to two-thirds of the total REE of the granitoids. Thus, the light REE dominate the total $\mathrm{REE}$, and the trend is basically a reflection of variation in contents of light REE. This dominance is graphically illustrated in figure 13 , where correlation coefficients of contents of individual REE are plotted relative to easterly distance across the batholith. The light REE show a high positive degree of correlation, the intermediate REE a poor correlation with $\mathrm{Eu}$ being slightly negative, and the heavy REE show progressively higher positive correlation coefficients. $\mathrm{La} / \mathrm{Yb}$ ratios, a measure of REE fractionation, and $\mathrm{Eu} / \mathrm{Eu}^{*}$ ratios show considerable scatter and no clearly discernible trends when projected onto a line crossing the batholith.

Tantalum also clearly increases eastward even though there is considerable scatter in the data (fig. 14). Barium does not show a clear trend completely across the batholith, but two samples suggest a sharp decrease of the element on the extreme west side of the batholith (fig. 15). A third low-Ba sample on the east side of the batholith probably has no geographic significance; it is discussed further in the following sections.

\section{VARIATIONS RELATIVE TO $\mathrm{SiO}_{2}$}

To further investigate compositional variations, $\mathrm{K}$, $\mathrm{Rb}, \mathrm{Cs}, \mathrm{Sr}, \mathrm{Ba}, \mathrm{Sc}, \mathrm{Fe}$, total $\mathrm{REE}$, and the ratios $\mathrm{La} / \mathrm{Yb}$

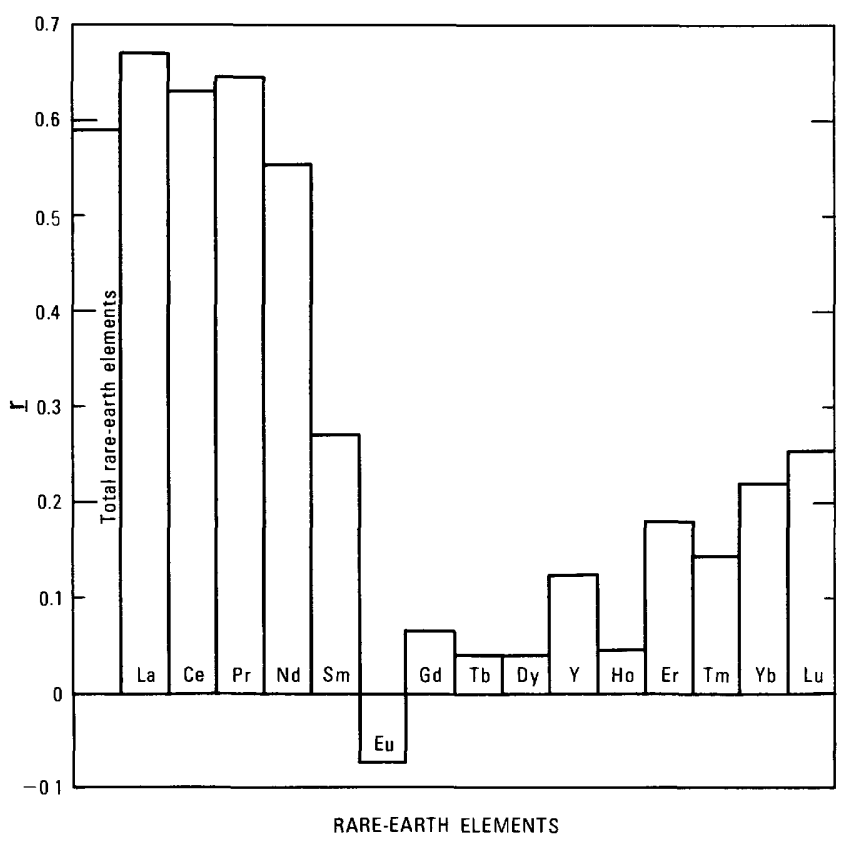

Figure 13.-Correlation coefficients $(r)$ of total rare-earth elements and individual rare-earth elements relative to easterly distance across the batholith. and $\mathrm{Eu} / \mathrm{Eu}^{*}$ have been plotted against $\mathrm{SiO}_{2}$, an index of differentiation in granitoid rocks (fig. 16). Hornblende-free and hornblende-bearing rocks have been distinguished on the plots; hornblende, which decreases as silica increases, is absent in rocks with more than 70-72 percent silica.

Several of the elements and elemental ratios show fundamental changes in trends at about 72 percent $\mathrm{SiO}_{2}$. One of the most pronounced changes is shown by $\mathrm{Sr}$, which displays considerable scatter and no discernible trend at $\mathrm{SiO}_{2}$ values below 72 percent, but between 72 and 74 percent $\mathrm{SiO}_{2}$ it drops abruptly from values greater than $300 \mathrm{ppm}$ to less than $200 \mathrm{ppm}$ and decreases to less than $100 \mathrm{ppm}$ at 80 percent $\mathrm{SiO}_{2}$. The $\mathrm{Eu} / \mathrm{Eu}^{*}$ ratio is relatively constant, but with scatter, from 55 to 72 percent $\mathrm{SiO}_{2}$, generally ranging from 0.6 to 1.0 , then drops abruptly above 72 percent $\mathrm{SiO}_{2}$ to

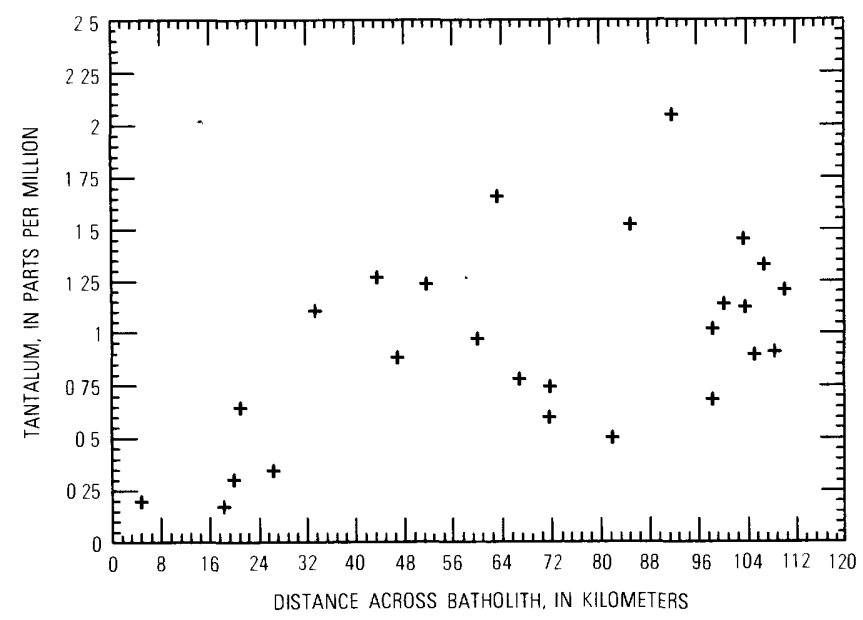

Figure 14.-Tantalum plotted onto a line approximately normal to the axis of the Sierra Nevada batholith.

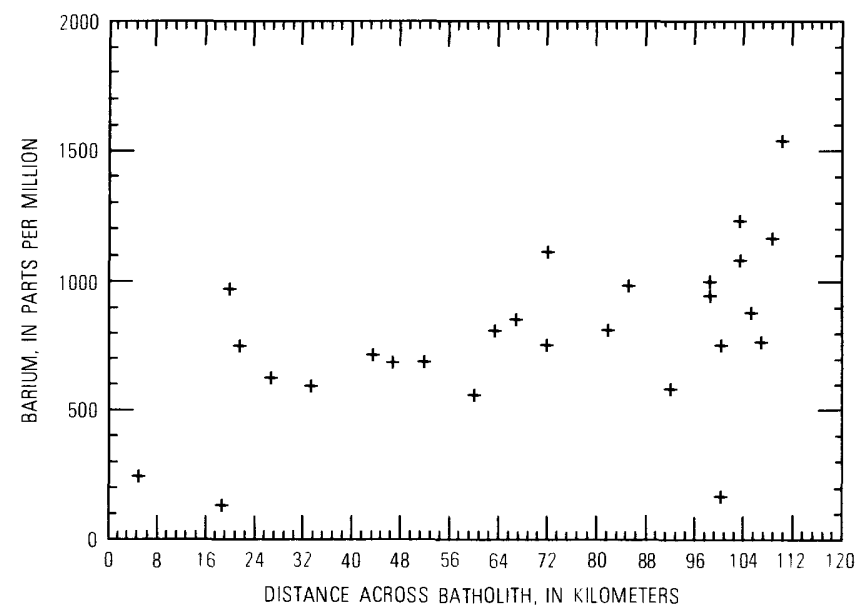

Figure 15.-Barium plotted onto a line approximately normal to the axis of the Sierra Nevada batholith. 

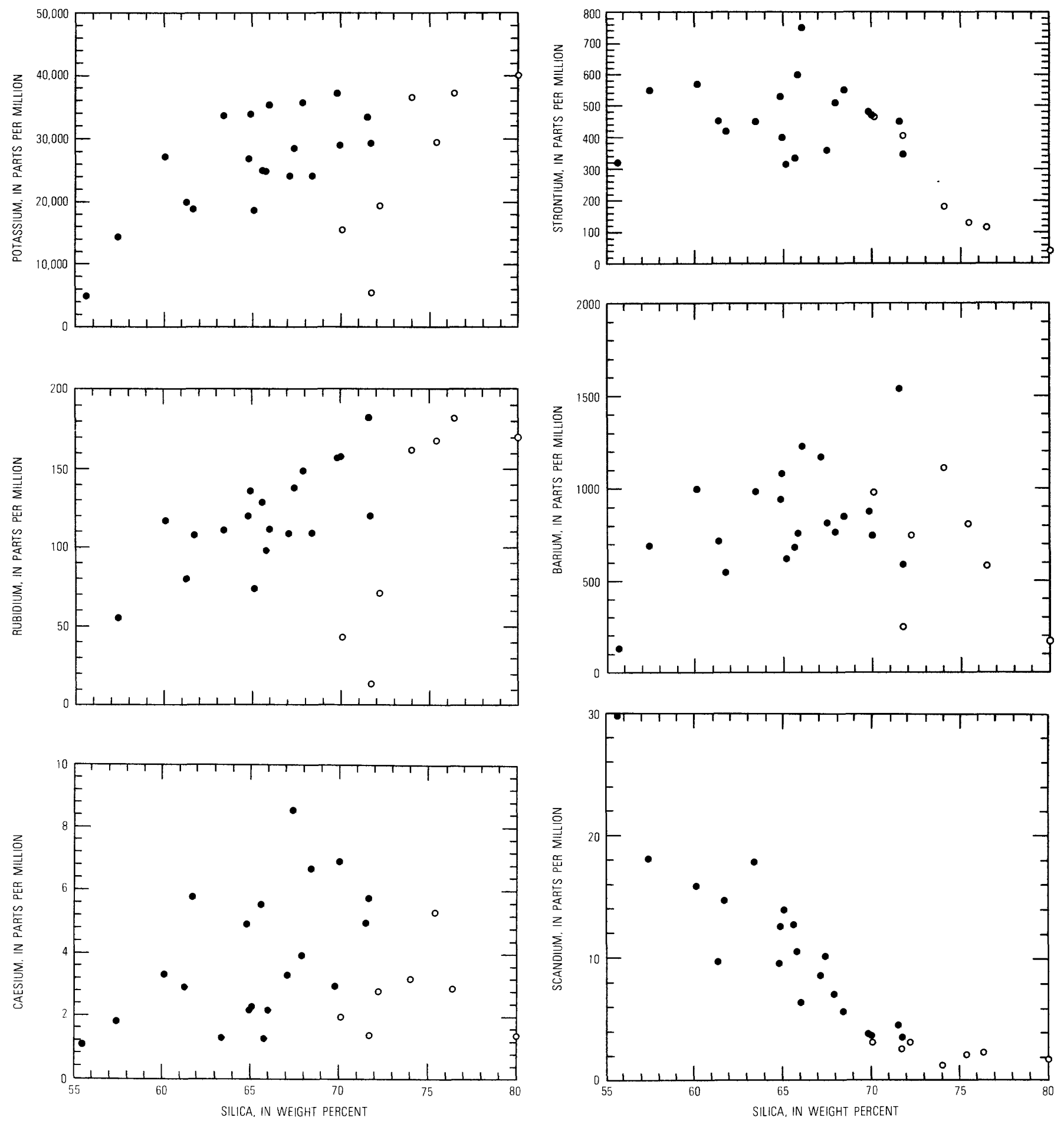

Figure 16.-Selected elements and elemental ratios plotted against silica for Sierra Nevada granitoids. Dots, hornblende-bearing granitoids; circles, hornblende-free granitoids.

values below 0.5 . The high $\mathrm{Eu} / \mathrm{Eu}^{*}$ value at 72 percent $\mathrm{SiO}_{2}$ is from a high $\mathrm{SiO}_{2}$, low $\mathrm{K}_{2} \mathrm{O}$, garnet-bearing trondhjemite from a borehole in the extreme western Sierra Nevada (sample ST-1). Total REE show consid- erable scatter throughout the entire range of $\mathrm{SiO}_{2}$ values, whereas the $\mathrm{La} / \mathrm{Yb}$ ratio shows a rather illdefined increasing trend with increasing $\mathrm{SiO}_{2}$ to about 70 percent, then even more scatter at higher $\mathrm{SiO}_{2}$ 

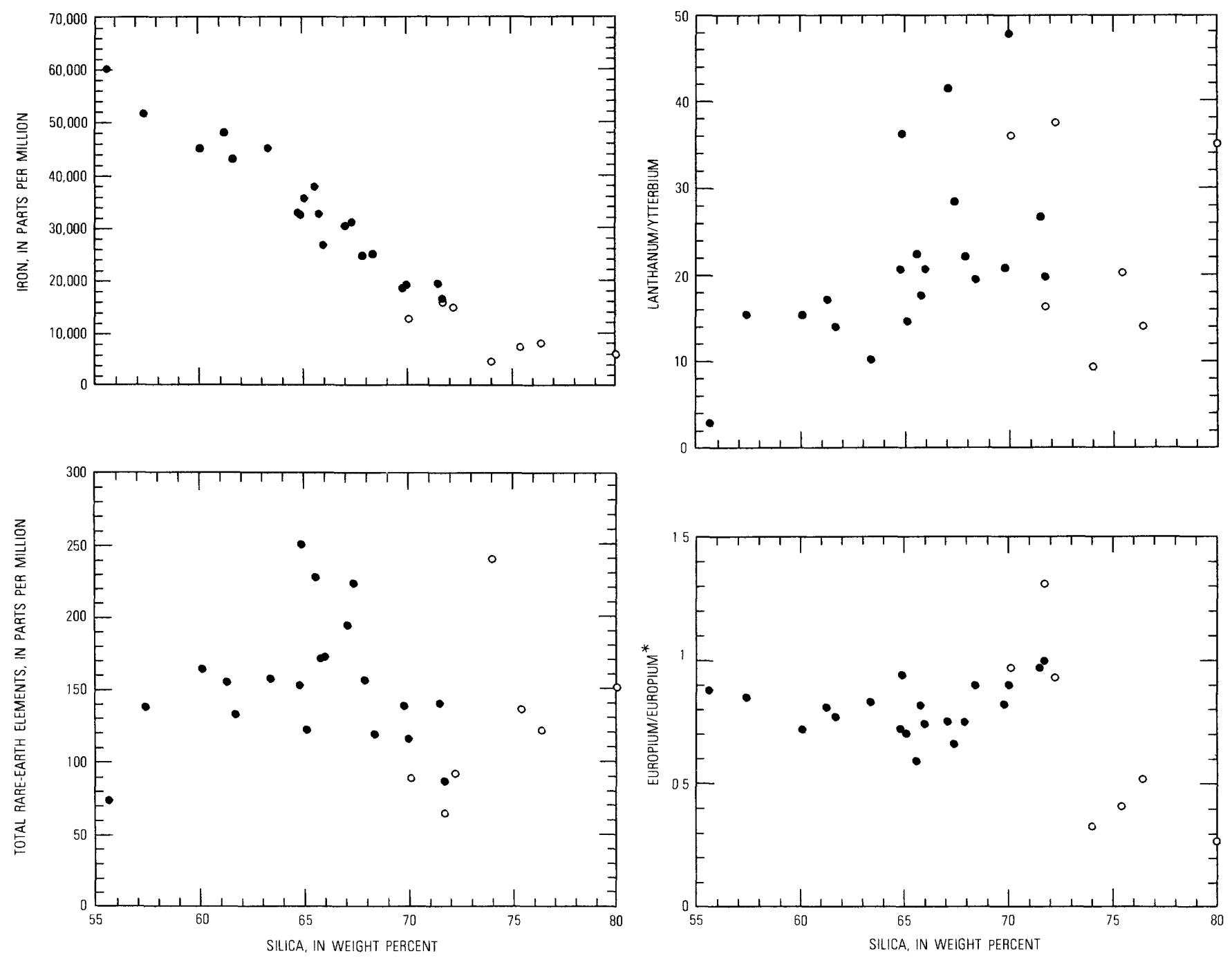

Figure 16.-Continued.

values. The plot of $\mathrm{Sc}$ against $\mathrm{SiO}_{2}$ shows a systematic decrease of $\mathrm{Sc}$ with increasing $\mathrm{SiO}_{2}$ to 70-72 percent $\mathrm{SiO}_{2}$. At higher $\mathrm{SiO}_{2}$ percentages, the Sc trend flattens, and the element stays fairly constant at about 2 ppm. Conversely, $\mathrm{Fe}$ does not exhibit a change in trend, progressively decreasing throughout the range of $\mathrm{SiO}_{2}$ values.

As an aid in evaluating plots of the trace alkali elements and $\mathrm{Ba}, \mathrm{K}$ has also been plotted against $\mathrm{SiO}_{2}$. $\mathrm{A}$ detailed discussion of variations of $\mathrm{K}_{2} \mathrm{O}$ relative to $\mathrm{SiO}_{2}$ in the central Sierra Nevada batholith has been presented by Bateman and Dodge (1970); they concluded that the $\mathrm{K}_{2} \mathrm{O} / \mathrm{SiO}_{2}$ ratio decreases systematically with decreasing $\mathrm{SiO}_{2}$ within individual intrusive sequences, but that the decrease is more pronounced in easterly sequences. Samples have not been distinguished by sequences on the plots herein; however, the samples with $\mathrm{K}$ contents less than $20,000 \mathrm{ppm}$ are all from the western Sierra Nevada and the three hornblende-free samples with low $\mathrm{K}$ contents are from the most westerly intrusive sequence. Excluding these three samples, there is an overall trend of increasing $\mathrm{K}_{2} \mathrm{O}$ with increasing $\mathrm{SiO}_{2}$, although there is considerable scatter in the data as several different sequences are represented on the $\mathrm{K}$ versus $\mathrm{SiO}_{2}$ plot. Rubidium behaves very similar to $\mathrm{K}$, increasing with increasing $\mathrm{SiO}_{2}$ with considerable scatter, and low $\mathrm{Rb}$, hornblende-free samples are all from the extreme western Sierra Nevada. In contrast, the $\mathrm{Cs}$ against $\mathrm{SiO}_{2}$ plot shows no discernible trend and considerable scatter. Barium values are also widely dispersed relative to $\mathrm{SiO}_{2}$. Two samples with low K from the western Sierra Nevada and one significant sample with the highest $\mathrm{K}$ and $\mathrm{SiO}_{2}$ from the eastern Sierra Nevada have Ba values con- 
siderably below the range of values of the other samples; this finding tends to confirm the earlier made statement that there is a rather poor correlation of $\mathrm{Ba}$ and $\mathrm{K}$ in these granitoid rocks.

\section{CONCLUSIONS}

Regional lateral chemical variations across the central Sierra Nevada batholith, particularly exemplified by $\mathrm{K}$ but including some other elements and ratios, have been attributed to changes in the compositions of the sources from which the magmas were derived. Thus, the eastward increase in total REE manifested particularly by the light REE, which confirms a trend noted by Dodge and Mays (1972) in sphenes from the granitoid rocks, is believed to be another reflection of these changes. Enrichment of light REE is characteristic of sediments of the earth's crust (Haskin and Frey, 1966), and the Sierra Nevada trend may be the result of progressively increasing amounts of crustally derived materials included easterly in juvenile, presumably mantle-derived material.

Eastward increasing depths of magma generation have been proposed as an alternative hypothesis to changes of source materials as a means of explaining lateral compositional variations across the Sierra Nevada (Dickinson, 1970; Kistler and Peterman, 1978). Green and Ringwood (1969) have suggested that chemical characteristics of various calc-alkaline suites are dependent on their depth of origin. According to their model, there is a continuum of fractionation processes with depth; at shallow levels of melting, magma compositions will largely be governed by separation of amphibole, at increasingly deeper levels, by separation of garnet, clinopyroxene, and amphibole, and finally at even greater depths by garnet and clinopyroxene. This model is difficult to evaluate, as Sierra Nevada granitoid rocks were derived from highly evolved magmas. A basalt or andesite source with a constant amount of melting or fractionation and a systematic progression of amphibole to garnet or simply increasing garnet separation could not have produced the lateral trend of eastward increasing total REE, as the REE partitioning pattern for garnet from basaltic and andesitic rocks intersects unity (that is, from where removal of the mineral will cause enrichment to where it will cause depletion) at intermediate REE (fig. 17). If increasing amounts of garnet separation or a shift from amphibole to garnet separation were responsible for light $\mathrm{REE}$ enrichment eastward, these kinds of separation would produce a concurrent depletion in heavy REE; this depletion was not observed. On the other hand, a decrease in the percent of melting along with a change from amphibole to residual garnet could buffer heavy REE while light REE increased. Depth-dependent processes at relatively shallow levels involving only increasing amphibole separation from a mafic source are unlikely, because although $\mathrm{K}$ and $\mathrm{Rb}$ contents increase eastward, the $\mathrm{K} / \mathrm{Rb}$ ratio does not change significantly (Dodge and others, 1970); amphiboles from basalts characteristically have high $\mathrm{K} / \mathrm{Rb}$ ratios (Hart and Aldrich, 1966), and increasing separation of amphibole would cause significant lowering of the $\mathrm{K} / \mathrm{Rb}$ ratio from resultant easterly magmas. Also Sc, which has been shown to be concentrated in Sierra Nevada hornblendes, would be expected to decrease eastward; it does not show significant lateral variation. In any case, $R E E$ variation, like that of $K$ and some other elements and ratios, is independent of the age of the granitic rocks, making it unlikely that this variation was necessarily caused by eastward increasing depth of magma generation.

As with total REE, the eastward increase in $\mathrm{Ta}$ is also thought to reflect a progressive shift in source materials. Wedepohl (1978) notes that Ta increases in weathered products relative to alkali, alkali earth, and

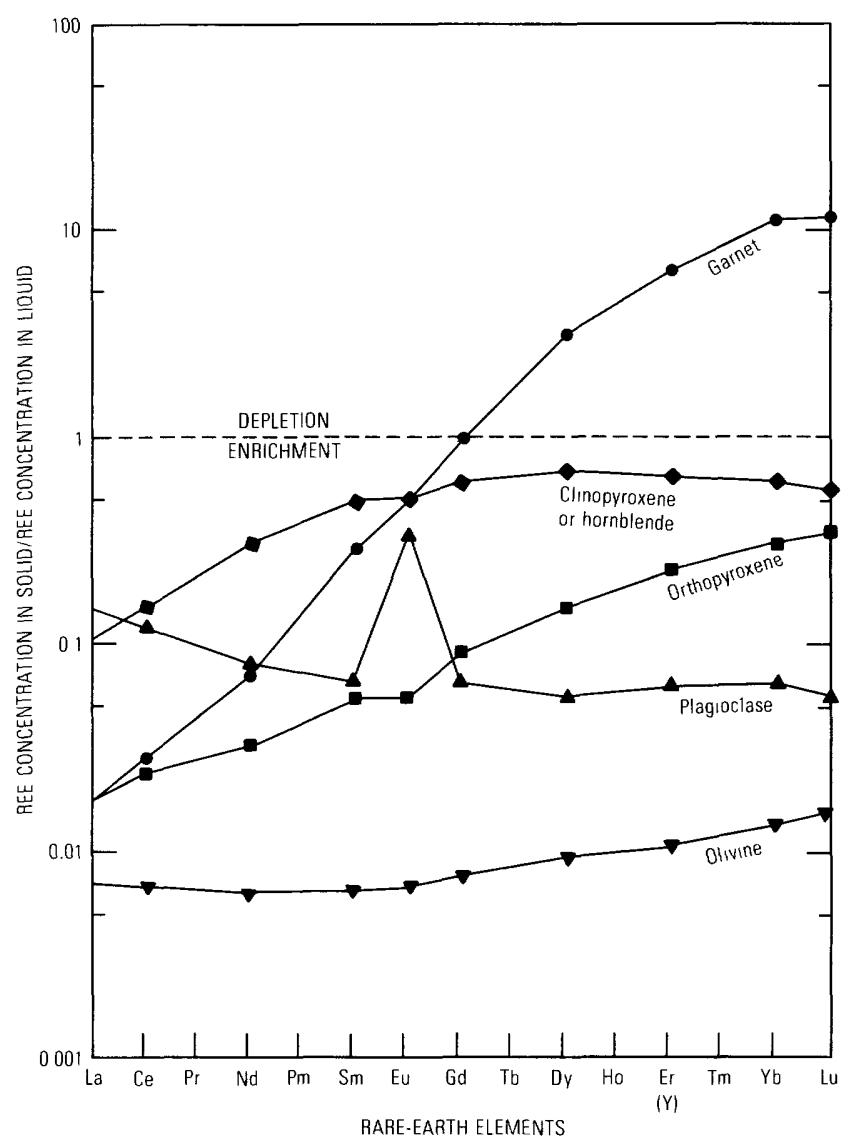

Figure 17. Solid/liquid distribution coefficients of rare-earth elements for minerals of mafic and intermediate rocks (from data compiled by Arth, 1976). 
several other major elements.

Age relations of contiguous sequences of the Sierra Nevada batholith generally indicate that the oldest plutons of the sequences are the most mafic, and the progressively younger plutons are increasingly more felsic. This succession has been explained by hypothesizing that each sequence was formed from a single fusion event, and subsequent fractional crystallization of the derived magmas formed individual plutons (Presnall and Bateman, 1973). Silica contents that do not systematically vary laterally across the batholith (Bateman and Dodge, 1970) are probably largely independent of differing source materials. Thus the amount of $\mathrm{SiO}_{2}$ offers a measure of fractionation of the granitoid rocks or degree of melting of source rocks, or both.

The systematic decrease of $\mathrm{Fe}$ and related elements with increasing $\mathrm{SiO}_{2}$ suggests continuous fractionation of ferromagnesian minerals throughout most of the differentiation history of Sierra Nevada magmas. Progressive decrease of Sc indicates that hornblende dominated the crystal fractionation when the $\mathrm{SiO}_{2}$ ranged from 55 to 72 percent. This reference is substantiated by the absence of hornblende in the granitoids that contain more than 72 percent $\mathrm{SiO}_{2}$. Biotite, on the other hand, apparently was of minor importance as a fractionate throughout differentiation in view of the considerable scatter of Cs relative to $\mathrm{SiO}_{2}$ and the general increase of $\mathrm{Rb}$ with increasing $\mathrm{SiO}_{2}$. Depletion of $\mathrm{Fe}$ above 72 percent $\mathrm{SiO}_{2}$ may merely reflect removal of small amounts of magnetite.

Below 72 percent $\mathrm{SiO}_{2}$, neither the $\mathrm{Eu} / \mathrm{Eu}^{*}$ ratios nor Sr values show systematic changes. This fact suggests that at lower $\mathrm{SiO}_{2}$ contents crystal fractionation of feldspar was overshadowed by hornblende fractionation. On the other hand, above 72 percent $\mathrm{SiO}_{2}$ both $\mathrm{Eu} / \mathrm{Eu}^{*}$ and $\mathrm{Sr}$ drop abruptly; this indicates significant depletion of feldspar at the higher $\mathrm{SiO}_{2}$ values. Although the plot of $\mathrm{Ba}$ against $\mathrm{SiO}_{2}$ is complicated with two low $\mathrm{Ba}$ rocks from the extreme western Sierra Nevada, the general absence of a trend suggests that the feldspar fractionate was plagioclase rather than K-feldspar. The low Ba content of the highest $\mathrm{SiO}_{2}$ rock in eastern Sierra Nevada implies K-feldspar was depleted, and the rock may be a true eutectic granite, having solidified from a magma from which both plagioclase and K-feldspar had fractionated.

\section{REFERENCES CITED}

Arth, J. G., 1976, Behavior of trace elements during magmatic processes-A summary of theoretical models and their applications: U.S. Geological Survey Journal of Research, v. 4, no. 1, p. 41-47.

Arth, J. G., and Barker, Fred, 1976, Rare-earth partitioning between hornblende and dacitic liquid and implications for the genesis of trondhjemitic-tonalitic magmas: Geology, v. 4, p. 534-536.

Bateman, P. C., and Chappell, B. W., 1979, Crystallization, fractionation, and solidification of the Tuolumne Intrusive Series, Yosemite National Park, California: Geological Society of America Bulletin, part 1, v. 90, p. 465-482.

Bateman, P. C., and Dodge, F. C. W., 1970, Variations of major chemical constituents across the central Sierra Nevada batholith: Geological Society of America Bulletin, v. 81, p. 409-420.

Bernotat, W. H., Carron, J. P., and Lagache, Martine, 1976, K/Rb and $\mathrm{Rb} / \mathrm{Cs}$ partition between $\mathrm{K}$-feldspars and biotites of preCambrian granites from Sinai: Tschermaks Mineralogische und Petrographische Mitteilungen, v. 23, p. 23-38.

Buma, Grant, Frey, F. A., and Wones, D. R., 1971, New England granites: trace element evidence regarding their origin and differentiation: Contributions to Mineralogy and Petrology, v. 31, p. $300-320$.

Carron, J.-P., and Lagache, Martine, 1972, Etude du partage des elements alcalins $\mathrm{Na}, \mathrm{K}, \mathrm{Li}, \mathrm{Rb}$, Cs entre les mineraux de quelques roches granitiques de France: 24th International Geological Congress Proceedings, Section 10, Montreal, 1972, p. 60-66.

Dickinson, W. R., 1970, Relations of andesites, granites, and derivative sandstones to arc-trench tectonics: Reviews of Geophysics and Space Physics, v. 8, p. 813-860.

Dodge, F. C. W., 1972a, Variation of ferrous-ferric ratios in the central Sierra Nevada batholith, U.S.A.: 24th International Geological Congress Proceedings, Section 10, Montreal, 1972, p. 12-19.

$1972 \mathrm{~b}$, Trace-element contents of some plutonic rocks of the Sierra Nevada batholith: U.S. Geological Survey Bulletin 1314F, p. F1-F 13 .

Dodge, F. C. W., Fabbi, B. P., and Ross, D. C., 1970, Potassium and rubidium in granitic rocks of central California, in Geological Survey research 1970: U.S. Geological Survey Professional Paper 700-D, p. D108-D115.

Dodge, F. C. W., and Mays, R. E., 1972, Rare-earth element fractionation in accessory minerals, central Sierra Nevada batholith, in Geological Survey research 1972: U.S. Geological Survey Professional Paper 800-D, p. D165-D168.

Dodge, F. C. W., Papike, J. J., and Mays, R. E., 1968, Hornblendes from granitic rocks of the central Sierra Nevada batholith, California: Journal of Petrology, v. 9, p. 378-410.

Dodge, F. C. W., Smith, V. C., and Mays, R. E., 1969, Biotites from granitic rocks of the central Sierra Nevada batholith, California: Journal of Petrology, v. 10, p. 250-271.

Evernden, J. F., and Kistler, R. W., 1970, Chronology of emplacement of Mesozoic batholithic complexes in California and western Nevada: U.S. Geological Survey Professional Paper 623, 42 p.

Frey, F. A., Chappell, B. W., and Roy, S. D., 1978, Fractionation of rare-earth elements in the Tuolumne Intrusive Series, Sierra Nevada batholith, California: Geology, v. 6, p. 239-242.

Gordon, G. E., Randle, K., Goles, G. G., Corliss, J. B., Beeson, M. H., and Oxley, S. S., 1968, Instrumental activation analysis of standard rocks with high resolution X-ray detectors: Geochimica et Cosmochimica Acta, v. 32, p. 369-396.

Gottfried, David, and Dinnin, J. I., 1965, Distribution of tantalum in some igneous rocks and coexisting minerals of the southern California batholith, in Geological Survey research 1965: U.S. Geological Survey Professional Paper 525-B, p. B96-B100.

Green, D. H., and Ringwood, A. E., 1969, High-pressure experimental studies on the origin of andesites, in McBurney, A. R., ed., Proceedings of the Andesite Conference: Oregon Department of Geology and Mineral Industries Bulletin 65, p. 21-32. 
Greenland, L. P., Gottfried, David, and Tilling, R. I., 1968, Distribution of manganese between coexisting biotite and hornblende in plutonic rocks: Geochimica et Cosmochimica Acta, v. 32, p. 1149-1163.

Greenland, L. P., Tilling R. I., and Gottfried, David, 1971, Distribution of cobalt between coexisting biotite and hornblende in igneous rocks: Neues Jahrbuch fur Mineralogie Monatshefte, v. 1, p. 33-42.

Hart, S. R., and Aldrich, L. T., 1966, Fractionation of potassium/ rubidium by amphiboles: implications regarding mantle composition: Science, v. 155, p. 325-327.

Haskin, L. A., and Frey, F. A., 1966, Dispersed and not-so-rare earths: Science, v. 152, p. 299-314.

Hermann, A. G., 1970, Yttrium and lanthides, in Wedepohl, K. H., ed., Handbook of geochemistry, V. II: Berlin, Springer-Verlag, p. $39,57-71-B-1$ to $39,57-71-0-9$.

Hertogen, J., and Gijbels, R., 1971, Instrumental neutron activation analysis of rocks with a low-energy photon detector: Analytica Chimica Acta, v. 56, p. 61-82.

Higuchi, Hideo, and Nagasawa, Hiroshi, 1969, Partition of trace elements between rock-forming minerals and the host volcanic rocks: Earth and Planetary Science Letters, v. 7, p. 281-287.

Hurley, P. M., Bateman, P. C., Fairbairn, H. W., and Pinson, W. H., Jr., 1965, Investigation of initial $\mathrm{Sr}^{87} / \mathrm{Sr}^{86}$ ratios in the Sierra Nevada plutonic province: Geological Society of America Bulletin, v. 76, p. 165-174.

Kistler, R. W., 1974, Phanerozoic batholiths in western North America: a summary of some recent work on variations in time, space, chemistry, and isotopic compositions: Earth and Planetary Science Annual Review, v. 2, p. 403-418.

Kistler, R. W., Bateman, P. C., and Brannock, W. W., 1965, Isotopic ages of minerals from granitic rocks of the central Sierra Nevada and Inyo Mountains, California: Geological Society of America Bulletin, v. 76, p. 155-164.

Kistler, R. W., and Peterman, Z. E., 1973, Variations in Sr, Rb, K, $\mathrm{Na}$, and initial $\mathrm{Sr}^{87} / \mathrm{Sr}^{86}$ in Mesozoic granitic rocks and intruded wall rocks in central California: Geological Society of America Bulletin, v. 84 , p. $3489-3512$.

1978, Reconstruction of crustal blocks of California on the basis of initial strontium isotopic compositions of Mesozoic granitic rocks: U.S. Geological Survey Professional Paper 1071, 17 p.

Lee, D. E., Mays, R. E., Van Loenen, R. E., and Rose, H. J., Jr., 1969, Accessory sphene from hybrid rocks of the Mount Wheeler mine area, Nevada, in Geological Survey research 1969: U.S. Geological Survey Professional Paper 650-B, p. B41-B46.

Lee, D. E., Van Loenen, R. E., and Mays, R. E., 1973, Accessory apatite from hybrid granitoid rocks of the southern Snake Range, Nevada: U.S. Geological Survey Journal of Research, v. 1, no. 1, p. 89-98.

Macdonald, G. A., 1941, Geology of the western Sierra Nevada between the Kings and San Joaquin Rivers, California: University of California Publications Bulletin of the Department of Geological Sciences, v. 17, p. 325-386.
Masuda, Yasuyuki, Yagi, Shinjiro, Nishimura, Susumu, and Asayama, Tetsuji, 1972, Rare-earth distributions in the Ibaragi granitic complex, Osaka Prefecture, Japan: Journal of the Geological Society of Japan, v. 78, no. 10, p. 521-530.

Naeser, C. W., and Dodge, F. C. W., 1969, Fission-track ages of accessory minerals from granitic rocks of the central Sierra Nevada batholith, California: Geological Society of America Bulletin, v. 80, p. 2201-2212.

Nagasawa, Hiroshi, 1970, Rare earth concentrations in zircons and apatites and their host dacites and granites: Earth and Planetary Science Letters, v. 9, no. 4, p. 359-364.

Nagasawa, Hiroshi, and Schnetzler, C. C., 1971, Partitioning of rare earth, alkali and alkaline earth elements between phenocrysts and acidic igneous magma: Geochmica et Cosmochimica Acta, v. 35 , no. 9, p. 953-968.

Piwinskii, A. J., 1968, Experimental studies of igneous rock series, central Sierra Nevada batholith, California: Journal of Geology, v. 76 , no. 5, p. 548-570.

Presnall, D. C., and Bateman, P. C., 1973, Fusion relations in the system $\mathrm{NaAlSi}_{3} \mathrm{O}_{8}-\mathrm{CaAl}_{2} \mathrm{Si}_{2} \mathrm{O}_{8}-\mathrm{SiO}_{2}-\mathrm{H}_{2} \mathrm{O}$ and generation of granitic magmas in the Sierra Nevada batholith: Geological Society of America Bulletin, v. 84, p. 3181-3202.

Schnetzler, C. C., and Philpotts, J. A., 1970, Partition coefficients of rare-earth elements between igneous matrix material and rockforming mineral phenocrysts-II: Geochimica et Cosmochimica Acta, v. 34, p. 237-243.

Staatz, M. H., Conklin, N. M., and Brownfield, I. K., 1977, Rare earths, thorium, and other minor elements in sphene from some plutonic rocks in west-central Alaska: U.S. Geological Survey Journal of Research, v. 5, no. 5, p. 623-628.

Stern, T. W., Bateman, P. C., Morgan, B. A., Newell, M. F., and Peck, D. L., 1981, Isotopic U-Pb ages of zircon from the granitoids of the central Sierra Nevada: U.S. Geological Survey Professional Paper 1185, $17 \mathrm{p}$.

Tilling, R. I., Greenland, L. P., and Gottfried, David, 1969, Distribution of scandium between coexisting biotite and hornblende in igneous rocks: Geological Society of America Bulletin, v. 80, p. 651-668.

Towell, D. G., Winchester, J. W., and Spirn, R. V., 1965, Rare-earth distributions in some rocks and associated minerals of the batholith of southern California: Journal of Geophysical Research, v. 70 , no. 14 , p. $3485-3496$.

Wedepohl, K. H., 1978, Tantalum, in Wedepohl, K. H., ed., Handbook of geochemistry, V. 2: Berlin, Springer-Verlag, p. 73-B-1 to 73-0-1.

Wollenberg, H. A., 1973, Fission-track radiography of uranium and thorium in radioactive minerals, in Jones, M.J., ed., Geochemical Exploration 1972: London Institute of Mining and Metallurgy, p. 347-358.

Wollenberg, H. A., and Smith, A. R., 1968, Radiogeologic studies in the central part of the Sierra Nevada batholith, California: Journal of Geophysical Research, v. 73, no. 4, p. 1481-1495. 
TABLES $1-7$ 
Table 1.-Rock units and locations of the representative samples

\begin{tabular}{|c|c|c|c|}
\hline $\begin{array}{c}\text { Sample } \\
\text { No. }\end{array}$ & $\begin{array}{l}\text { USGS } 15^{\prime} \\
\text { quadrangle }\end{array}$ & $\begin{array}{l}\text { Lati tude } \\
(\text { N.) }\end{array}$ & $\begin{array}{c}\text { Longitude } \\
(\text { W. })\end{array}$ \\
\hline \multicolumn{4}{|c|}{ John Muir intrusive sequence (Bateman and Dodge, 1970) } \\
\hline MG-1------- & Lamarck Granodiorite-1..- Mount Goddard-a- & $37^{\circ} 13^{\prime}$ & $118^{\circ} 36^{\prime}$ \\
\hline MT-2----.-- & Round Valley Peak Granodiorite-- & $37^{\circ} 28^{\prime}$ & $118^{\circ} 43^{\prime}$ \\
\hline $\mathrm{BCa}-20-\ldots$ & Mount Givens Granodiorite--.....- Blackcap Mountain--.- & $37^{\circ} 14^{\prime}$ & $118^{\circ} 57^{\prime}$ \\
\hline BCC-12.-..- & - do & $37^{\circ} 05^{\prime}$ & $118^{\circ} 58^{\prime}$ \\
\hline$H C-1------$ & - do- $^{-}$ & $37^{\circ} 08^{\prime}$ & $118^{\circ} 59^{\prime}$ \\
\hline R-99-.....-- & Alaskite of Evolution Basin-- & $37^{\circ} 07^{\prime}$ & $118^{\circ} 38^{\prime}$ \\
\hline \multicolumn{4}{|c|}{ Shaver intrusive sequence (Bateman and Dodge, 1970) } \\
\hline$S L-1-\cdots--$ & 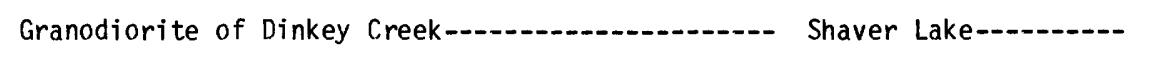 & $37^{\circ} 06^{\prime}$ & $119^{\circ} 18^{\prime}$ \\
\hline $\mathrm{BCC}-13-\ldots$ & -- do-- Blackcap Mountain-..- & $37^{\circ} 01^{\prime}$ & $118^{\circ} 59^{\prime}$ \\
\hline SL-18--...- & 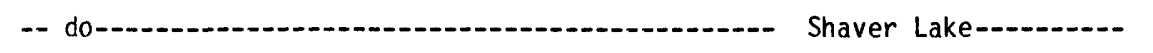 & $37^{\circ} 09^{\prime}$ & $119^{\circ} 18^{\prime}$ \\
\hline HL-29--.-.- & Quartz monzonite of Dinkey Dome--..--_-_-_-_-- Huntington Lake----- & $37^{\circ} 10^{\prime}$ & $119^{\circ} 06^{\prime}$ \\
\hline FD-12------ & Taft Granite-1.-- Yosemite-1, & $37^{\circ} 43^{\prime}$ & $119^{\circ} 36^{\prime}$ \\
\hline \multicolumn{4}{|c|}{ Fine Gold intrusive sequence (Stern and others, 1981) } \\
\hline CL-1--.-.-. & Pyroxene quartz diorite of Macdonald (1941)--- Clovis-- & $36^{\circ} 54^{\prime}$ & $120^{\circ} 04^{\prime}$ \\
\hline JB-1 -..--- & Tonalite of Blue Canyon-- Shaver Lake-1- & $37^{\circ} 06^{\prime}$ & $119^{\circ} 23^{\prime}$ \\
\hline WV-1-...-. & 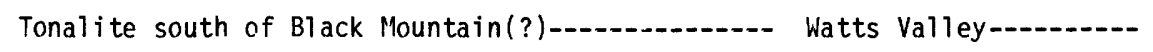 & $36^{\circ} 58^{\prime}$ & $119^{\circ} 29^{\prime}$ \\
\hline S.]-1--..-- & Plagiogranite of Ward Mountain- Millerton Lake-1. & $37^{\circ} 06^{\prime}$ & $119^{\circ} 44^{\prime}$ \\
\hline SL-32------ & Tonal ite of Blue Canyon-- Shaver Lake-- & $37^{\circ} 02^{\prime}$ & $119^{\circ} 23^{\prime}$ \\
\hline ST-1---...- & Tonalite of Sherman Thomas drill hole-- Le Grand-1.- & $37^{\circ} 10^{\prime}$ & $120^{\circ} 04^{\prime}$ \\
\hline FD-20------ & Granodiorite of Knowles & $37^{\circ} 12^{\prime}$ & $119^{\circ} 53^{\prime}$ \\
\hline \multicolumn{4}{|c|}{ Palisade intrusive sequence (Bateman and Dodge, 1970) } \\
\hline MG-3------ & 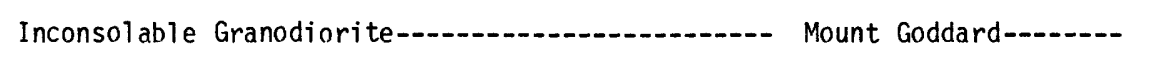 & $37^{\circ} 07^{\prime}$ & $118^{\circ} 31^{\prime}$ \\
\hline BP-2------ & 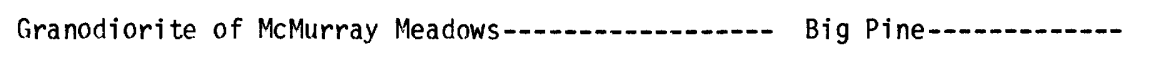 & $37^{\circ} 06^{\prime}$ & $118^{\circ} 22^{\prime}$ \\
\hline BP-1-2---- & Tinemaha Granodiorite-1. & $37^{\circ} 07^{\prime}$ & $118^{\circ} 27^{\prime}$ \\
\hline FD-2------- & Hunter Mountain Quartz Monzonite-- & $36^{\circ} 48^{\prime}$ & $118^{\circ} 02^{\prime}$ \\
\hline FD-4-..--- & 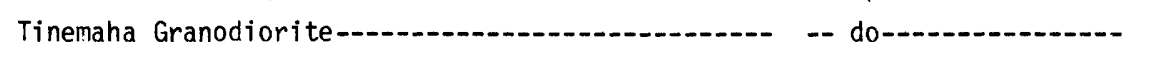 & $36^{\circ} 57^{\prime}$ & $118^{\circ} 08^{\prime}$ \\
\hline FD-3------ & Paiute Monument Quartz Monzonite--- & $36^{\circ} 49^{\prime}$ & $118^{\circ} 02^{\prime}$ \\
\hline \multicolumn{4}{|c|}{ Scheelite intrusive sequence (Bateman and Dodge, 1970) } \\
\hline MT-1------- & Wheeler Crest Quartz Monzonite-1.- Mount Tom- & $37^{\circ} 23^{\prime}$ & $118^{\circ} 38^{\prime}$ \\
\hline MG-2------ & Tungsten Hills Quartz Monzonite--.-- Mount Goddard--.-- & $37^{\circ} 14^{\prime}$ & $118^{\circ} 36^{\prime}$ \\
\hline \multicolumn{4}{|c|}{ Unassigned metamorphosed granitic rock } \\
\hline KR-------- & Granodiorite of the Goddard pendant--..--_---- Blackcap Mountain---- & $37^{\circ} 12^{\prime}$ & $118^{\circ} 47^{\prime}$ \\
\hline
\end{tabular}




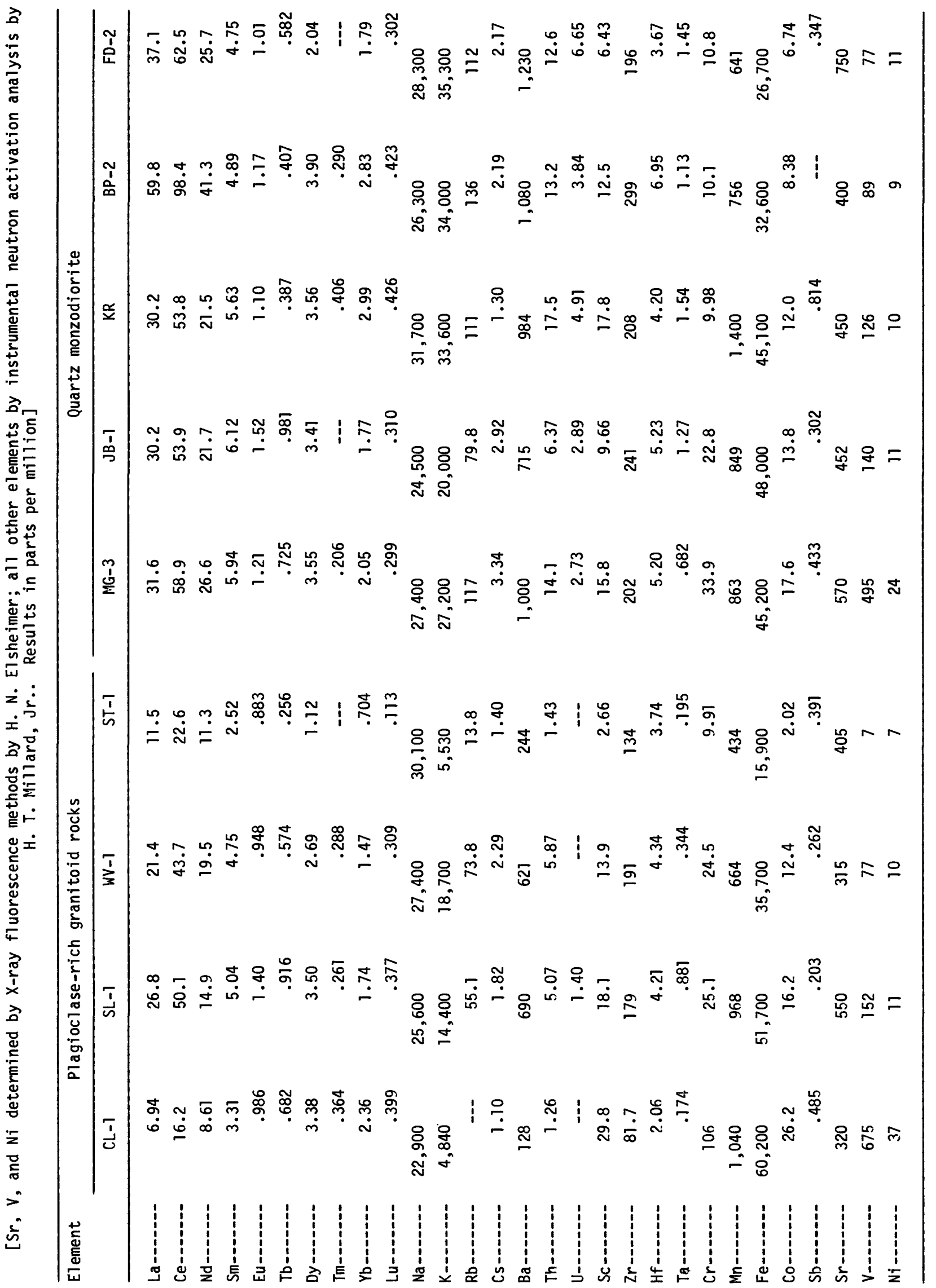




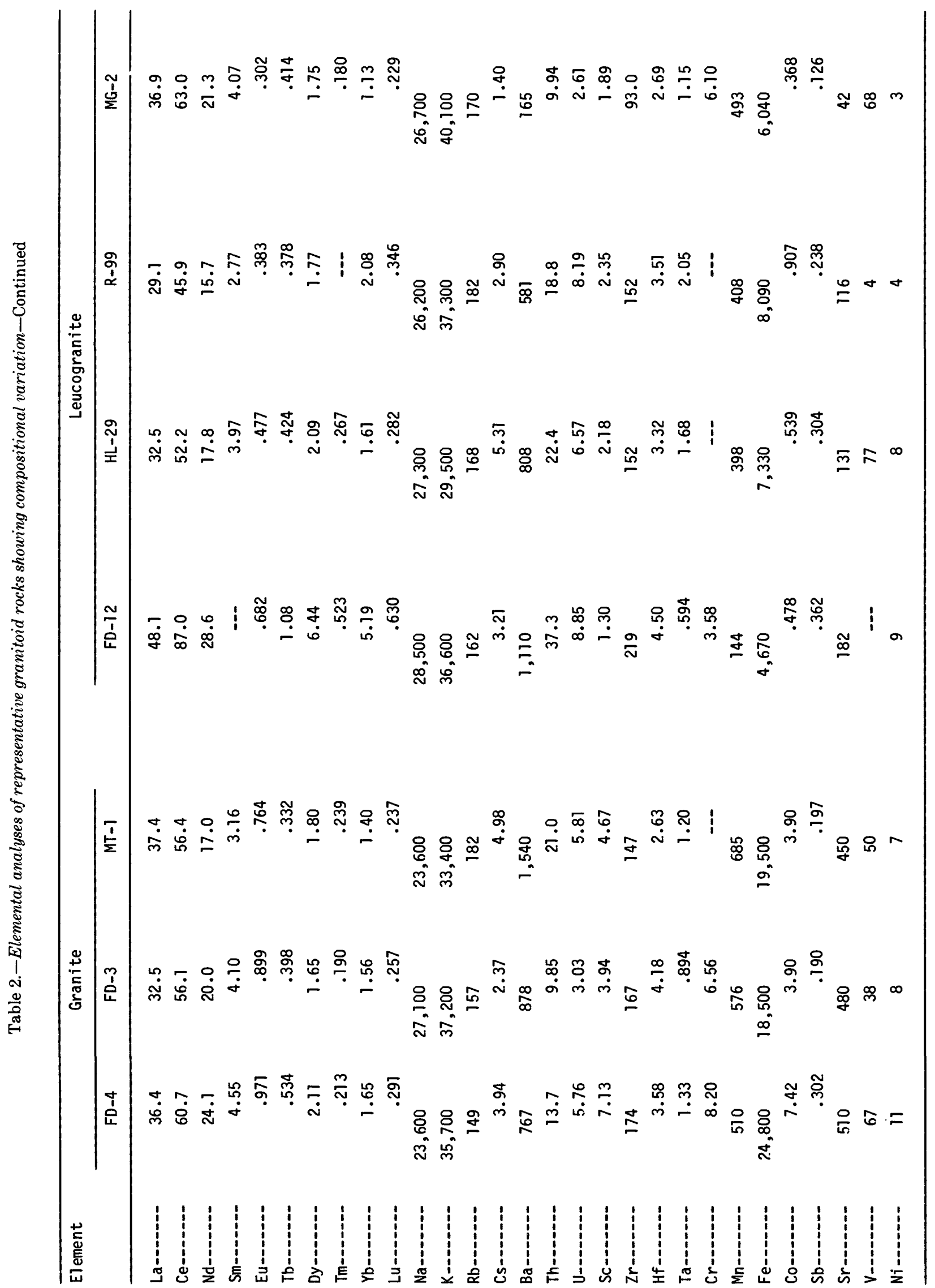




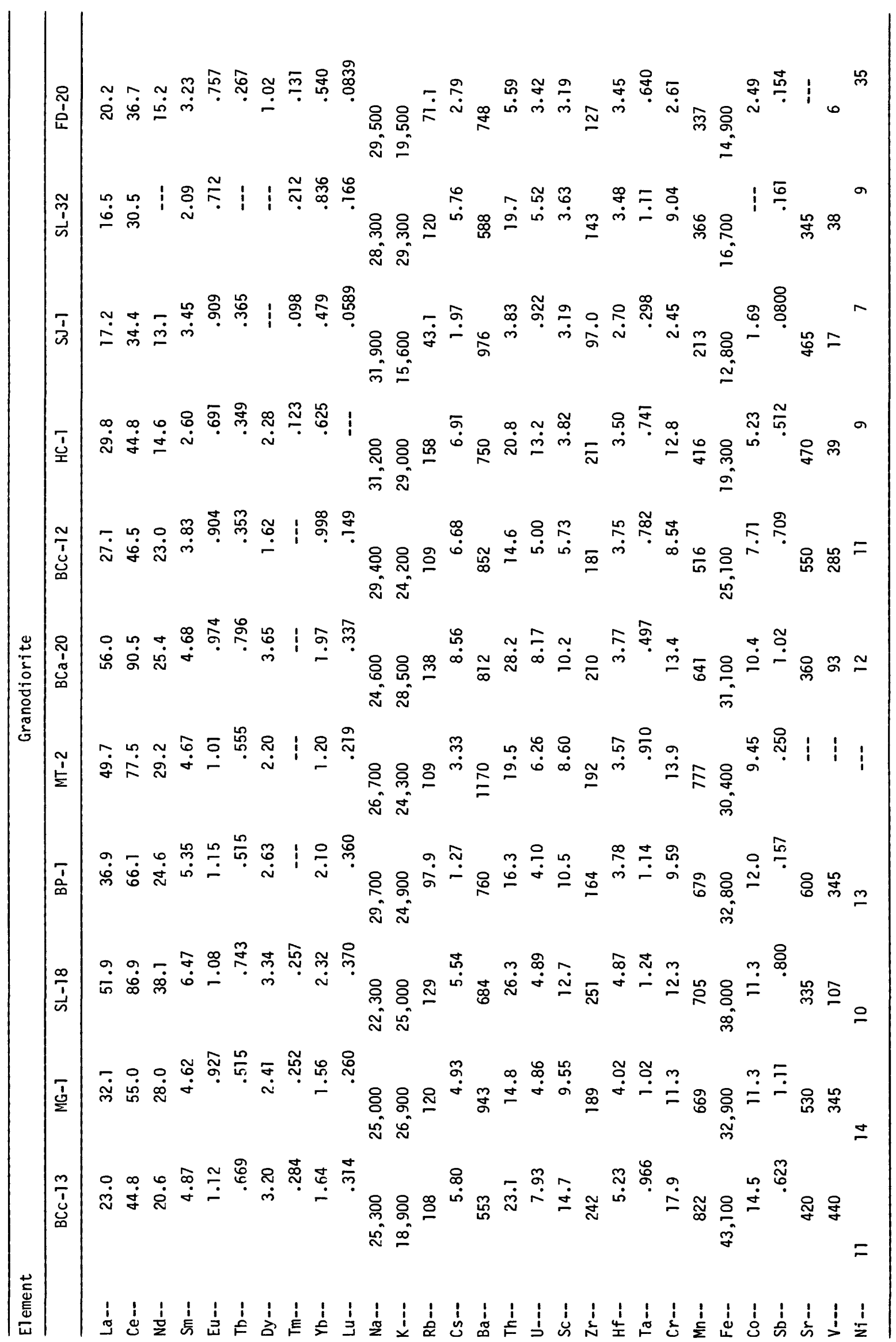

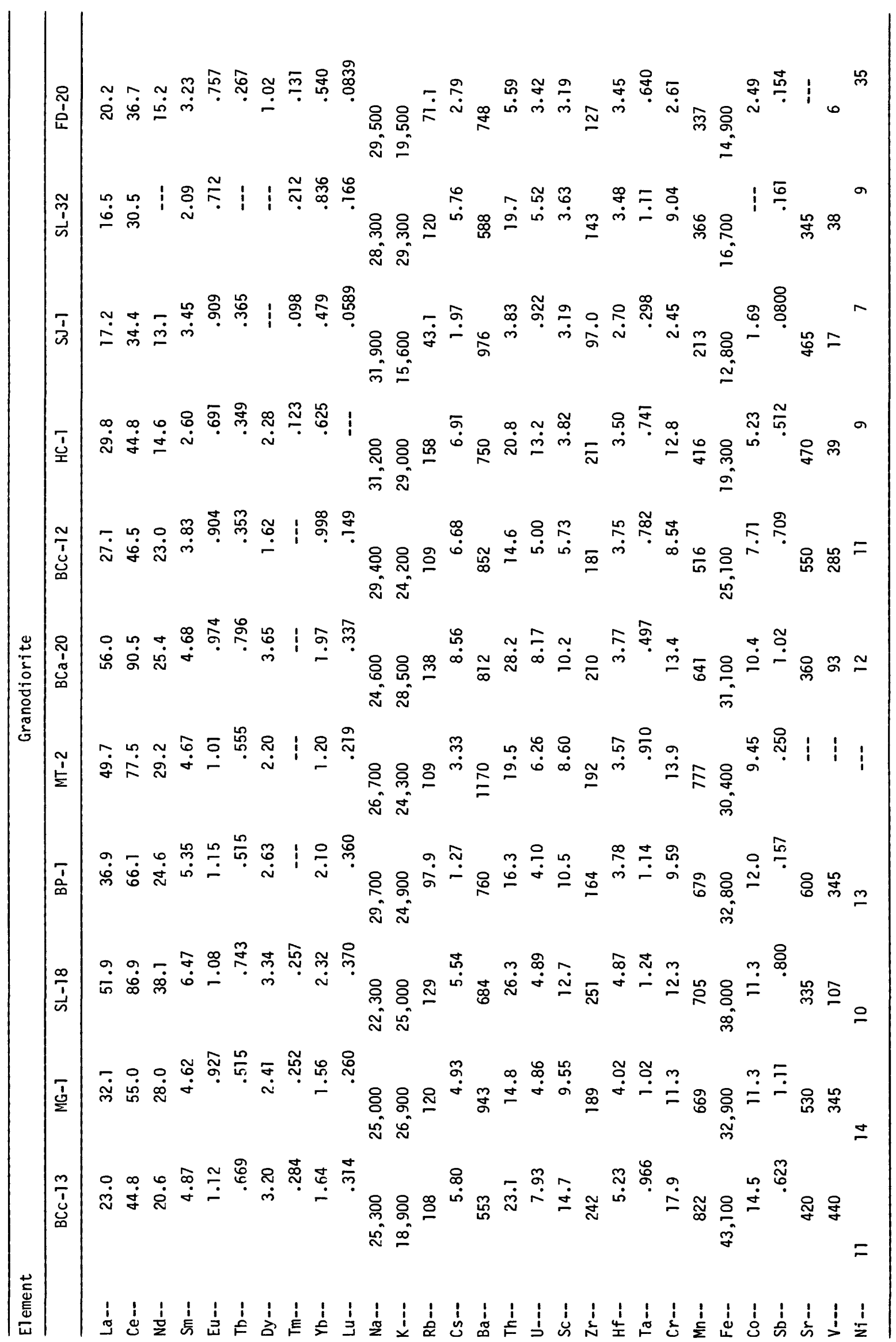




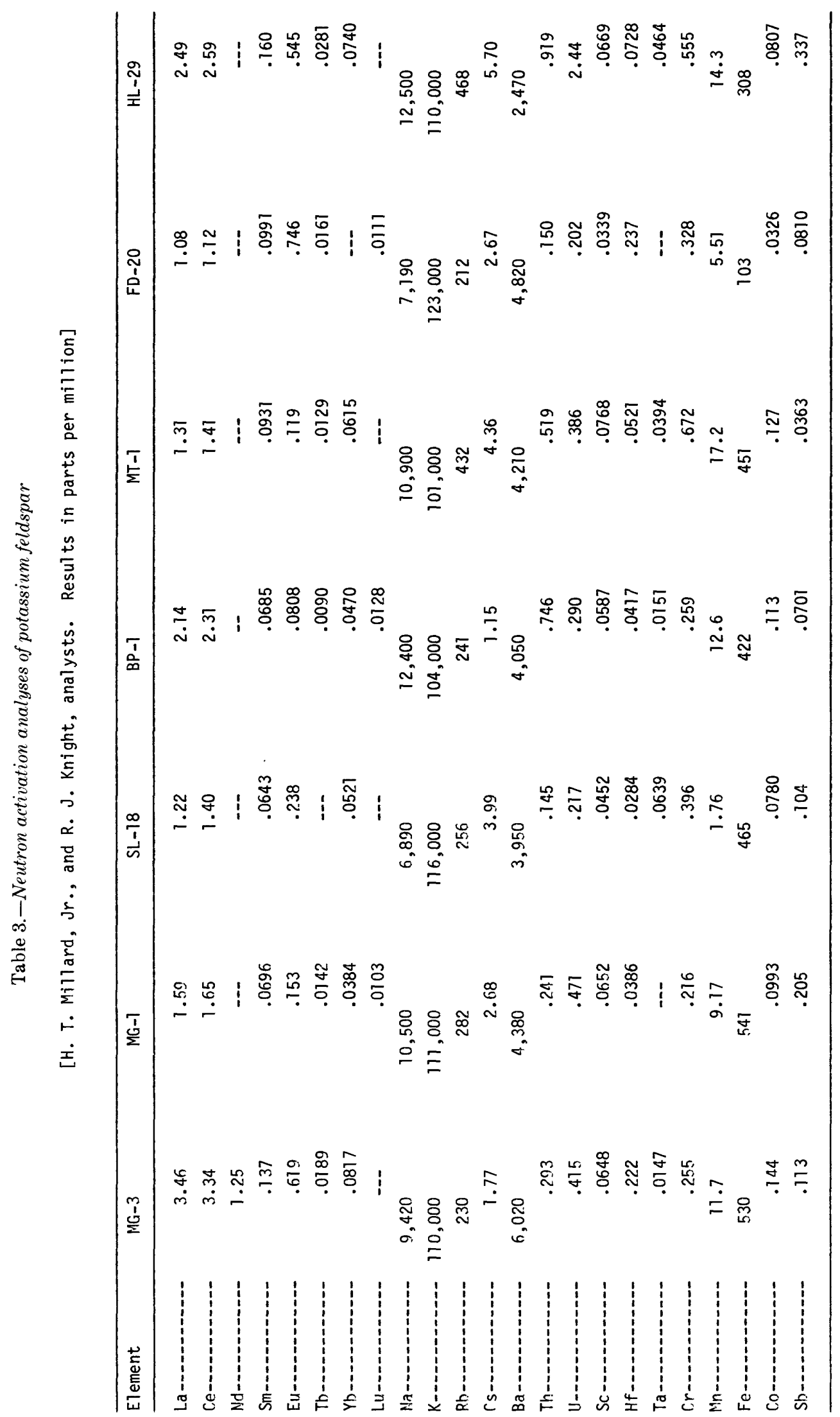


Table 4.-Neutron activation analyses of plagioclase and plagioclase+quartz concentrates

[Analyzed by H. T. Millard, Jr., and R. J. Knight. Results in parts per million]

\begin{tabular}{|c|c|c|c|c|}
\hline \multirow[t]{2}{*}{ Element } & \multirow{2}{*}{$\frac{\text { Plagioclase }}{\text { CL-1 }}$} & \multicolumn{3}{|c|}{ Plagioclase and quartz } \\
\hline & & MG-1 & $S L-18$ & $B P-1$ \\
\hline La--------------- & 4.60 & 3.84 & 3.03 & 6.19 \\
\hline 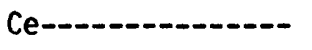 & 5.65 & 3.60 & 3.73 & 6.01 \\
\hline 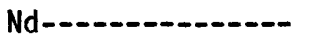 & 2.04 & 1.22 & 1.44 & 1.79 \\
\hline Sm- & .224 & .118 & .141 & .156 \\
\hline 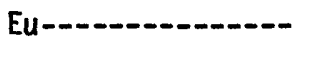 & .611 & .157 & .291 & .243 \\
\hline Tb-1.- & .0191 & .0163 & .0171 & .0223 \\
\hline 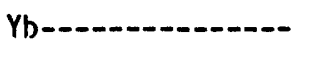 & .0416 & .0310 & .0488 & .0478 \\
\hline Lu--_-_---_--.-- & .0042 & --- & --- & .0133 \\
\hline $\mathrm{Na}-\mathrm{-}-\mathrm{-}-\mathrm{-}-\mathrm{-}$ & 38,700 & 25,400 & 24,400 & 32,400 \\
\hline K---n- & 2,740 & 2,630 & 1,670 & 3,060 \\
\hline 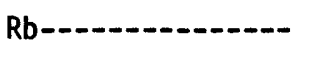 & 2.36 & 9.39 & 7.43 & 10.6 \\
\hline 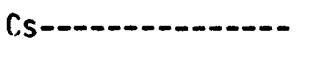 & .0882 & .495 & 2.62 & .266 \\
\hline Ba--_-_-_-_-_--- & 193 & 99.8 & 87.9 & 174 \\
\hline Th-.-.-. & .136 & .337 & .704 & 1.28 \\
\hline 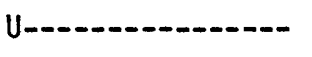 & .0908 & .444 & .662 & .437 \\
\hline Sc-- & .115 & .0623 & .0492 & .182 \\
\hline Hf & .0261 & .0840 & .193 & .0810 \\
\hline 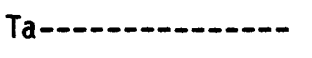 & --- & --- & .0079 & .0157 \\
\hline Cr-ar & .414 & .278 & .362 & --- \\
\hline 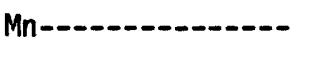 & 23.0 & 9.66 & 6.89 & 21.8 \\
\hline Fe-- & 1,960 & 516 & 561 & 827 \\
\hline 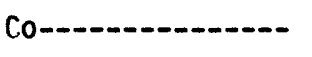 & .883 & .121 & .111 & .295 \\
\hline Sb-- & .0950 & .141 & .252 & .0773 \\
\hline
\end{tabular}


Table 5.-Neutron activation analyses of biotite

[H. T. Millard, Jr., and R. J. Knight, analysts. Results in parts per million]

\begin{tabular}{|c|c|c|c|c|c|c|}
\hline El ement & $M G-3$ & KR & $W V-1$ & $M G-1$ & $S L-18$ & $\mathrm{BP}-1$ \\
\hline Ce--.-n-n- & 3.64 & 10.9 & 3.97 & 6.24 & 6.34 & 6.34 \\
\hline 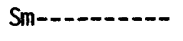 & .326 & 1.03 & .408 & .510 & .714 & .503 \\
\hline Eu--_....--- & 1.32 & .202 & .050 & .160 & .206 & .194 \\
\hline Yb-...-.---- & -- & .469 & .233 & --- & --- & .230 \\
\hline $\mathrm{Na}-\ldots$ & 681 & 894 & 604 & 939 & 822 & 957 \\
\hline K-_......... & 69,600 & 104,000 & 74,200 & 72,000 & 78,400 & 75,200 \\
\hline Rb-- & 639 & 567 & 498 & 744 & 768 & 792 \\
\hline 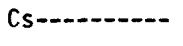 & 28.0 & 10.1 & 18.3 & 37.0 & 59.8 & 28.6 \\
\hline Ba--_-..-..- & 930 & 413 & 1,330 & 672 & 897 & 526 \\
\hline Th--------- & .671 & 5.59 & 1.29 & 1.04 & 2.44 & 1.46 \\
\hline Ta-_....... & .607 & .291 & 1.91 & .213 & .534 & .0921 \\
\hline Cr---n-n--- & 95.0 & 17.2 & 125 & 59.8 & 57.8 & 32.0 \\
\hline 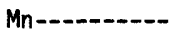 & 2320 & 6780 & 2,260 & 3,190 & 2,450 & 3,220 \\
\hline Fe--_- & 136,000 & 125,000 & 154,000 & 134,000 & 149,000 & 122,000 \\
\hline Co---:------ & 88.0 & 69.9 & 64.6 & 87.2 & 68.1 & 81.7 \\
\hline \multirow[t]{2}{*}{ Sb-.........- } & .209 & .350 & .157 & .508 & .722 & .299 \\
\hline & $\mathrm{BCa}-20$ & MT-1 & SL-32 & ST-1 & $F D-20$ & $H L-29$ \\
\hline La-.........-. & 2.43 & 4.01 & 6.61 & .736 & .503 & 2.32 \\
\hline Ce--_-......- & 4.05 & 4.90 & 4.29 & -- & -- & 3.85 \\
\hline $\mathrm{Rb}-\ldots$ & 869 & 1,210 & 845 & 302 & 609 & 1,740 \\
\hline 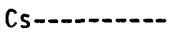 & 80.6 & 77.9 & 60.6 & 23.6 & 30.1 & 157 \\
\hline Ba--_- & 902 & 279 & 549 & 2,790 & 1,800 & 1,330 \\
\hline Th-.-......... & 1.10 & 1.77 & 3.96 & .109 & .287 & 1.79 \\
\hline 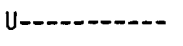 & .543 & 1.06 & 1.77 & .343 & .327 & 3.72 \\
\hline Sc-...-.-.-- & 11.4 & 8.67 & 15.1 & 15.9 & 32.0 & 70.1 \\
\hline Hf---------- & .190 & .592 & .265 & 3.68 & .364 & .395 \\
\hline Ta-_-_-_-- & .293 & .311 & .507 & 2.52 & 7.94 & 27.0 \\
\hline 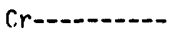 & 52.3 & 11.7 & 79.4 & 31.1 & 22.5 & 9.23 \\
\hline Mn------.-- & 2,820 & 8,130 & 3,440 & 1,280 & 3,360 & 9,190 \\
\hline Fe--------- & 136,000 & 121,000 & 156,000 & 160,000 & 159,000 & 178,000 \\
\hline 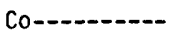 & 76.8 & 45.0 & 63.1 & 36.6 & 37.3 & 26.6 \\
\hline $\mathrm{Sb}-\ldots$ & .313 & .140 & .237 & --- & .455 & \\
\hline
\end{tabular}




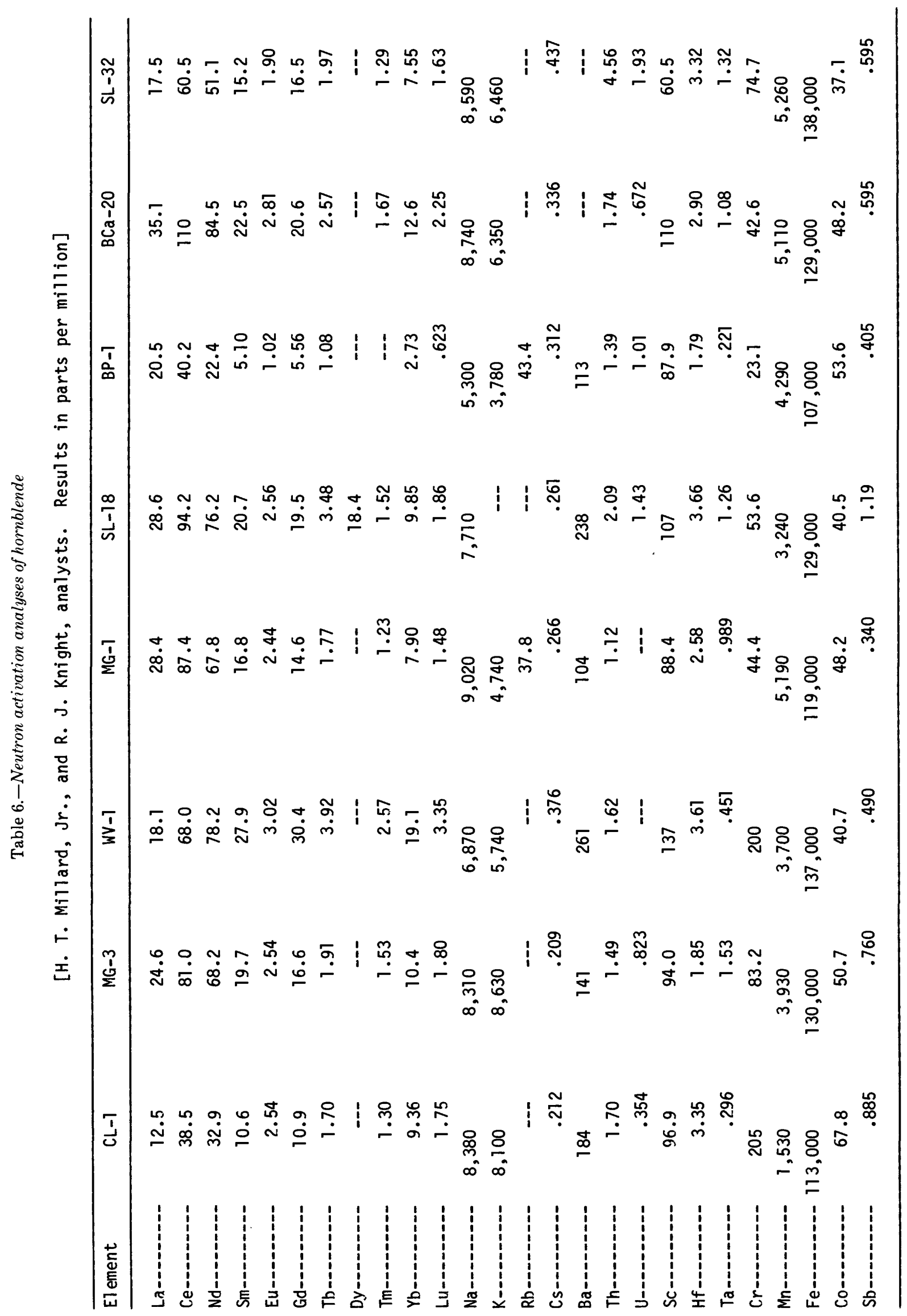




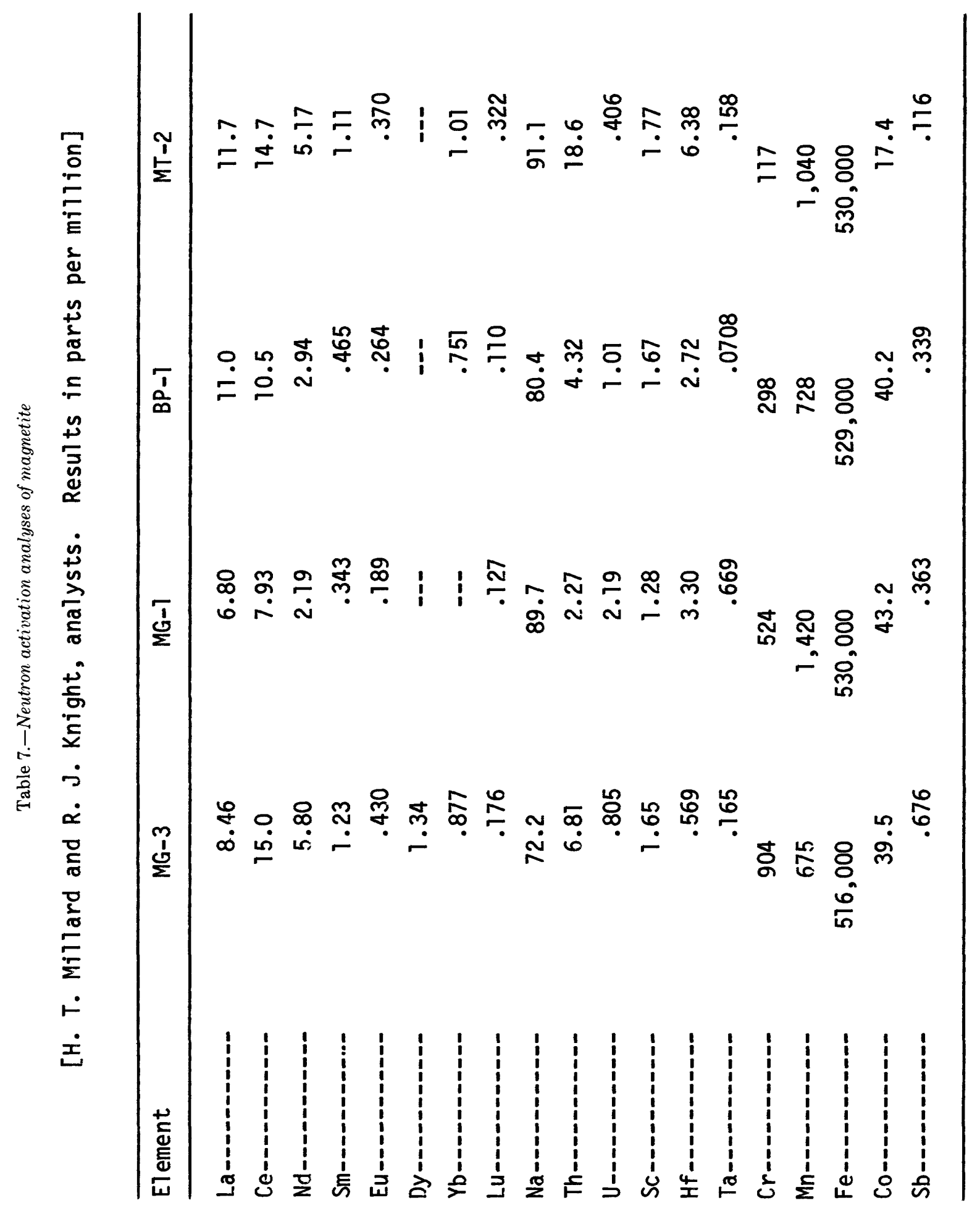

